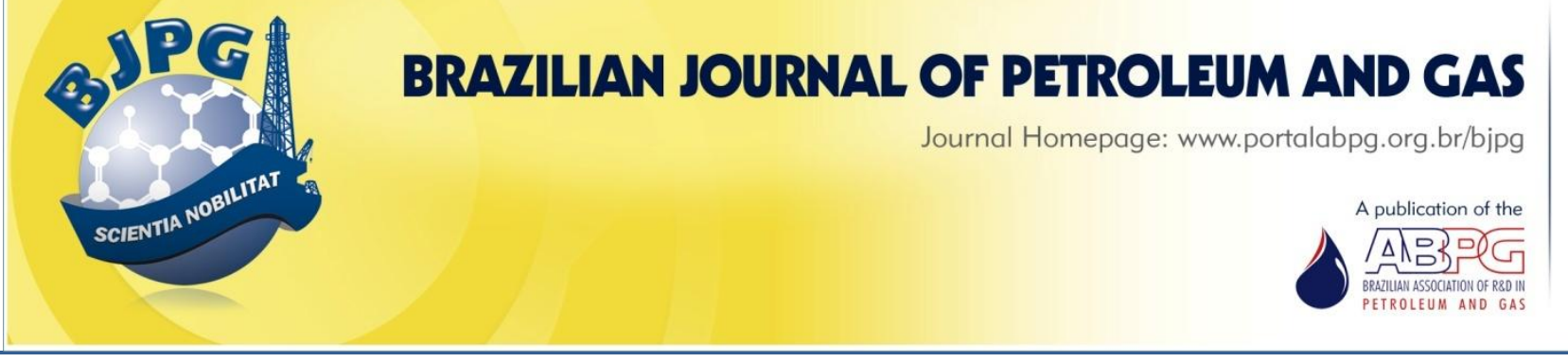

\title{
COMPARISON OF PVT CORRELATIONS FOR PREDICTING CRUDE OIL PROPERTIES: THE BRAZILIAN CAMPOS BASIN CASE STUDY
}

\author{
${ }^{a}$ Mangili, P. V. ${ }^{1}$; Ahón, V. R. R. \\ ${ }^{a}$ Fluminense Federal University, Department of Chemical and Petroleum Engineering, Niterói - RJ - Brazil \\ Received: 15.01.2019 / Revised: 10.07.2019 / Accepted: 17.07.2019 / Published on line: 08.10.2019
}

\begin{abstract}
Pressure-Volume-Temperature correlations are essential for estimating the required parameters necessary for the identification of reservoir fluid properties when experimental laboratory data are not readily available. Although several models have been published for different oil fields, there is a lack of studies addressing the Brazilian pre-salt region. Hence, in this paper we compared twenty empirical correlations for the determination of the solution gas-oil ratio, oil formation-volume-factor, and undersaturated oil viscosity for Brazilian pre-salt oil samples collected from the Campos Basin region, originally evaluated by Elias and Trevisan (2016). From our statistical results, some models presented good estimation performances when compared to said reference's results. In fact, through a statistical analysis, Al-Shammasi (2001)'s correlation proved to be the best estimation method for solution gas-oil ratio, whereas Al-Marhoun (1985) and Beal's (1946) correlations were deemed the most accurate for the prediction of oil formation-volume-factor and under-saturated oil viscosity, respectively.
\end{abstract}

\section{KEYWORDS}

Campos Basin; oil formation-volume-factor; PVT correlations; gas-oil ratio solution; under-saturated oil viscosity

\footnotetext{
${ }^{1}$ To whom all correspondence should be addressed.

Address: Fluminense Federal University, Department of Chemical and Petroleum Engineering, Niterói - RJ - Brazil. ZIP Code: 24210-240 | e-mail: pmangili@id.uff.br doi:10.5419/bjpg2019-0013
} 


\section{INTRODUCTION}

The oil and gas industry may be deemed one of the most dynamic engineering spheres to be studied. This is due to not only the wearying technical knowledge required to provide the community with fine, daily life-demand commodities but also the wavy behavior associated with such an industry. In fact, the Management Centre Europe (2018) stated that the petroleum market has been facing notable oscillations in the last decades, especially with regard to the new finds - which are located more frequently in remote areas - and the changes in supply and demand necessities driven mainly by population growth, globalization, and climate change.

In light of such dynamics, the oil and gas companies have been committed to either developing new techniques or improving alreadyexisting strategies to produce the so-called "black gold." Therefore, understanding the phase behavior of hydrocarbons present in the reservoir is of utmost importance, since it is highly necessary for process design (Rasouli et al., 2008), evaluation of reservoir performance (Elsharkawy et al., 1995), and field development (Torabi et al., 2014). The thermodynamic behavior of petroleum fluids can be determined through Pressure-VolumeTemperature (PVT) tests, which are conducted on laboratory samples collected in situ. PVT analyses are essential for providing the required parameters necessary for the identification of reservoir fluid properties such as bubble point pressure $\left(P_{b}\right)$, solution gas-oil ratio $\left(R_{s}\right)$, and oil formationvolume-factor $\left(B_{0}\right)$ (Karimnezhad et al., 2014; Salehinia et al., 2016). Nevertheless, PVT analyses depend on experimental data that may not be readily available. In this regard, empirical correlations may be conveniently useful for estimating such parameters, which can be carried out by using field measured data such as temperature, oil gravity, and gas density, among others (Gharbi \& Elsharkawy, 2003).

This paper aims to demonstrate the significance of applying PVT correlations in the estimation of reservoir fluid properties in the absence of laboratory data. We compared twenty empirical correlations for the determination of the solution gas-oil ratio, oil formation-volume-factor and under-saturated viscosity $\left(\mu_{\mathrm{o}}\right)$ for oil samples from Brazilian pre-salt reserves originally evaluated by
Elias and Trevisan (2016). To the best of our knowledge, such a comparison has not yet been performed for pre-salt reservoir fluids and, specifically, from the Campos Basin region.

In the next section, a brief revision regarding the main correlations is presented. In Section 3, we describe the procedures for calculating $\mathrm{P}_{\mathrm{b}}, \mathrm{B}_{\mathrm{o}}$ and $\mu_{\mathrm{o}}$, as well as the comparison approach, whereas in Section 4 we discuss the results. Finally, in Section 5 , we summarize the main findings and provide some suggestions for future studies.

\section{LITERATURE SURVEY}

\subsection{PVT properties}

As previously discussed, reservoir engineers frequently are challenged to design production facilities to process crude oil so as to achieve the highest economic performance. They must, therefore, understand the phase behavior of hydrocarbons throughout the entire lifetime of the reservoir and be able to estimate fluid properties that depend on different conditions of temperature and pressure. According to Ahmed (2010), these properties are determined preferably through laboratory analyses that consist in studying the volumetric behavior of live oil samples, which are, then, characterized by being subjected to several pressure level changes in a PVT cell.

The results obtained from experimental PVT tests are essential for geophysics and engineers to perform material balance calculations and reservoir simulation studies, identify potential risks, determine reserve recovery, and develop production plans (Mansour et al., 2013; Potsch et al., 2017). For this reason, oil samples must preserve the same characteristics as their original formation to provide reliable, high quality data, and, thus, "reduce uncertainty" and "improve investment efficiency" (Nnabuo et al., 2014).

However, as mentioned earlier, experimental data may not be available, especially due to the inaccessibility of samples during the early project stage when only surface tests are carried out. Hence, the lack of laboratory measurements led practitioners to use empirical correlations for estimating the volumetric behavior of reservoir 
Table 1. Examples of PVT correlations ${ }^{a}$.

\begin{tabular}{lll}
\hline Model & Parameter & Location \\
\hline Katz (1942) & $\mathrm{B}_{\mathrm{o}}$ & North America \\
Standing (1947) & $\mathrm{P}_{\mathrm{b}}$ and $\mathrm{B}_{\mathrm{o}}$ & California \\
Elam (1957) & $\mathrm{P}_{\mathrm{b}}$ and $\mathrm{B}_{\mathrm{o}}$ & Texas \\
Lasater (1958) & $\mathrm{P}_{\mathrm{b}}$ & U.S.A. and Canada \\
Knopp and Ramsey (1960) & $\mathrm{B}_{\mathrm{o}}$ and $\mathrm{R}_{\mathrm{s}}$ & Venezuela \\
Caixerio (1976) & $\mathrm{B}_{\mathrm{o}}$ & Brazil \\
Glasø (1980) & $\mathrm{P}_{\mathrm{b}}$ and $\mathrm{B}_{\mathrm{o}}$ & North Sea \\
Vazquez and Beggs (1980) & $\mu_{\mathrm{od}}, \mathrm{P}_{\mathrm{b}}, \mathrm{B}_{\mathrm{o}}$ and $\mathrm{R}_{\mathrm{s}}$ & Global data bank \\
Al-Marhoun (1985) & $\mathrm{P}_{\mathrm{b}}$ and $\mathrm{B}_{\mathrm{o}}$ & Middle East \\
Obomanu and Okpobiri (1987) & $\mathrm{B}_{\mathrm{o}}$ and $\mathrm{R}_{\mathrm{s}}$ & Nigeria \\
Abdul-Majeed and Salman (1988) & $\mathrm{B}_{\mathrm{o}}$ & Iraq \\
Dokla and Osman (1992) & $\mathrm{P}_{\mathrm{b}}$ and $\mathrm{B}_{\mathrm{o}}$ & United Arab Emirates \\
Petrosky and Farshad (1993) & $\mathrm{P}_{\mathrm{b}}, \mathrm{B}_{\mathrm{o}}$ and $\mathrm{R}_{\mathrm{s}}$ & Gulf of Mexico \\
Kartoatmodjo and Schmidt (1994) & $\mu_{\mathrm{od}}, \mathrm{C}_{\mathrm{o}}, \mathrm{P}_{\mathrm{b}}$ and $\mathrm{B}_{\mathrm{o}}$ & Global data bank \\
\hline$\mu_{\mathrm{od}}$ : Dead oil viscosity. $\mathrm{C}_{\mathrm{o}}$ : Under-saturated oil compressibility. &
\end{tabular}

fluids in terms of different pressure and temperature conditions (Asadisaghandi \& Tahmasebi, 2011; Karimnezhad et al., 2014). Said models have been used widely for estimating reservoir fluid properties, comparing data with laboratory results to identify associated errors and determine the quality of samples.

Numerous studies regarding the foundation of PVT correlations have been developed, among which some examples are disclosed in Table 1. We note that the majority of the correlations published so far refer to North American fields, where the oil industry started to develop since the first oil well drilling in 1859. We can also observe that bubble point pressure, solution gas-oil ratio, and oil formation-volume-factor received the most attention due to the fact that, according to Olatunji, Selamat, \& Raheem (2011), "they are the most essential factors in reservoir and production computations".

According to Ahmed (2010), the bubble point pressure refers to the pressure at which the first gas bubble is formed as the mixture is expanded isothermally. It is measured usually through laboratory tests and determined either by the visualization of the first bubbles or graphically in a pressure to volume (PV) diagram, as shown in Figure 1. The PV diagram is obtained through Constant Composition Expansion experiments. Red and blue curves correspond to the two-phase and one-phase regions, respectively, whereas the inflection point represents the value of $P_{b}$.

The oil formation volume factor, in turn, refers to the total volume of oil required to produce one barrel under standard conditions, i.e. at $60^{\circ} \mathrm{F}$ and

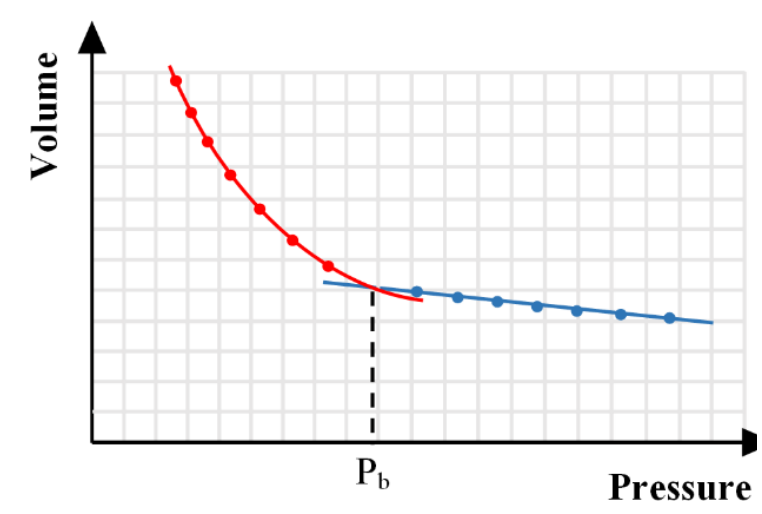

Figure 1. Generic PV diagram. 


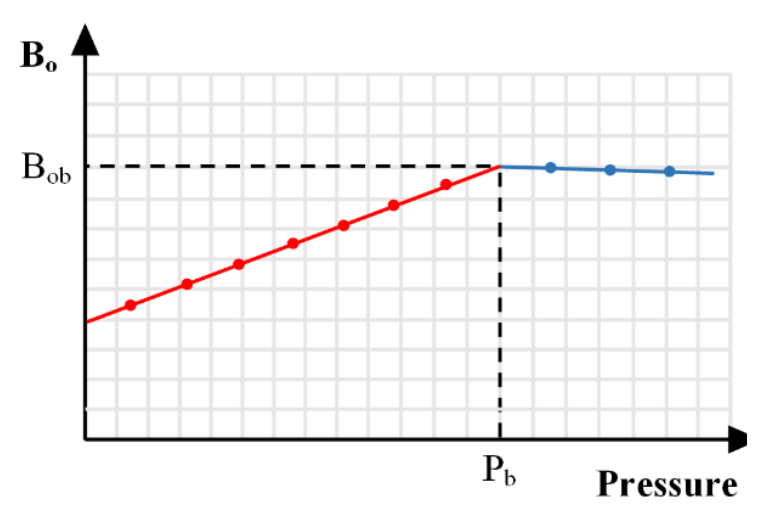

Figure 2. Generic chart for $B_{0}$ dependence on the pressure.

14.7 psia, according to the American Petroleum Institute. It can be determined as shown in Equation 1, in which $V_{R}$ corresponds to the volume of oil and dissolved gas under reservoir temperature $(T)$ and pressure $(P)$, and $V_{o}$ denotes the volume of oil under standard conditions (SC) (Mahdiani \& Kooti, 2016).

$\mathrm{B}_{\mathrm{o}}=\frac{\left(\mathrm{V}_{\mathrm{R}}\right)_{\mathrm{T}, \mathrm{P}}}{\left(\mathrm{V}_{\mathrm{o}}\right)^{\mathrm{SC}}}$

Plot results related to $B_{o}$ data are obtained through Differential Liberation experiments, as shown in Figure 2, which illustrates how such variable is affected by the pressure. Red and blue curves refer to the two and one-phase regions, respectively, while the inflection point corresponds to the value of the formation volume factor at the bubble point $\left(B_{o b}\right)$ (Rasouli et al., 2008). We observed that below $P_{b}$, as the pressure increases, the liquid phase becomes richer in dissolved gas, increasing $V_{R}$. On the other hand, above $P_{b}$ the gas is interpreted as being completely dissolved and, therefore, $B_{0}$ becomes nearly constant since it depends solely on the compressibility of the liquid phase (Pedersen et al., 2015).

Finally, the solution gas-oil ratio $\left(R_{s}\right)$ is defined as the measure of the volume of dissolved gas in relation to the volume of oil produced. It can be calculated as given by Equation 2, where $\mathrm{V}_{\mathrm{g}}$ and $\mathrm{V}_{\mathrm{o}}$ denote the volume of dissolved gas produced and the volume of oil in the stock tank, respectively; both under standard conditions (SC) (Pedersen et al., 2015).

$$
\mathrm{R}_{\mathrm{s}}=\frac{\left(\mathrm{V}_{\mathrm{g}}\right)^{S C}}{\left(\mathrm{~V}_{\mathrm{o}}\right)^{\mathrm{SC}}}
$$

Plot results related to $R_{s}$ data are also obtained through Differential Liberation experiments, as depicted in Figure 3, which shows the dependence of $R_{s}$ on the pressure. Red and blue curves represent the two-phase and one-phase regions, respectively, while the inflection point refers to the value of the solution gas-oil ratio at the bubble point $\left(R_{s b}\right)$ (Ahmed, 2010). $R_{s}$ is constant above $P_{b}$ since all the gas to be produced is dissolved totally in the liquid phase. Below $P_{b}$, in turn, the volume of dissolved gas - and hence $R_{s}$ - increases as the pressure increases.

Although the development of empirically derived correlations allowed engineers to overcome possible issues of unavailability and unreliability associated with laboratory analyses, usually, they are not deemed as fully accurate. Various correlations have poor prediction for some points and are not flexible to be tunned globally due to differences in fluid characteristics, which vary for each location (Rafiee-Taghanaki et al., 2013). In this regard, researches started to apply computer-based techniques for predicting PVT properties due to their precision, speed and ability to process large data sets in a fast way, especially in the cases where the fluid composition is known. This is particularly true in the case of studies that deal with modeling and tuning equations of state (EOS), which have been usually carried out to describe phase behavior and fluid PVT properties

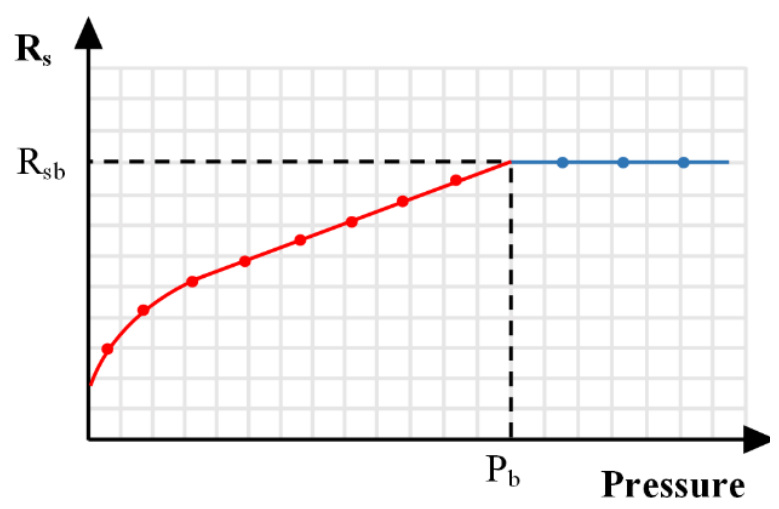

Figure 3. Generic chart for $R_{s}$ dependence on the pressure. 


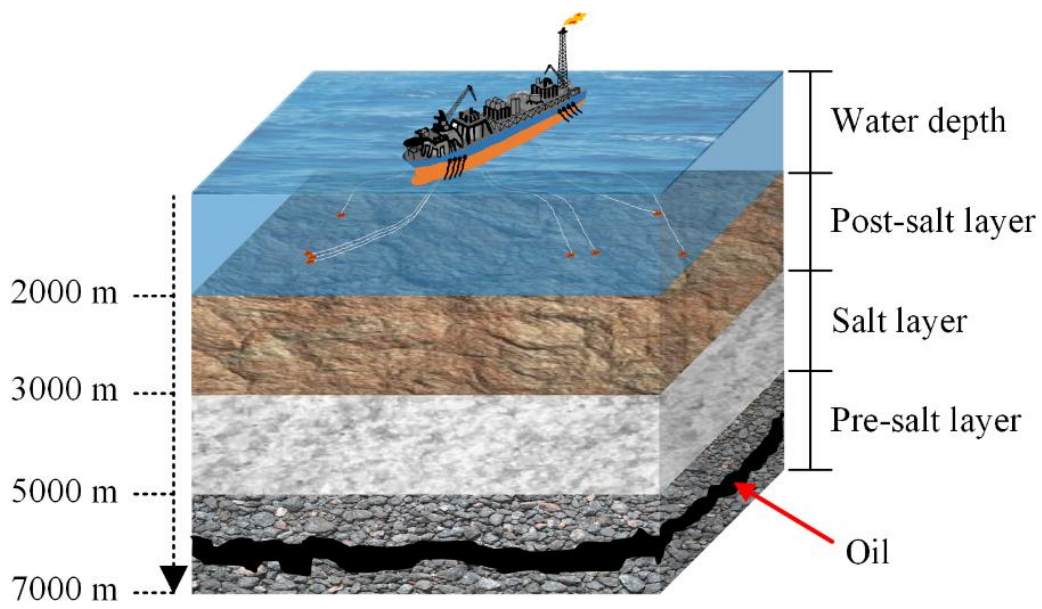

Figure 4. Brazilian pre-salt layer.

for a wide variety of mixtures from different regions (Mansour et al., 2013; Ahmadi et al., 2019). However, according to Olatunji et al. (2011), EOS models require well-defined composition data and depend heavily on fluid characteristics and tuning procedures. To overcome such drawbacks, numerous practitioners have resorted to other computational strategies that may include, but are not limited to, artificial neural networks (Asadisaghandi \& Tahmasebi, 2011; Talebi et al., 2014; Mahdiani \& Kooti, 2016); support vector machine (Rafiee-Taghanaki et al., 2013; Khamis \& Fattah, 2019); and fuzzy logic systems (Olatunji et al., 2011; Salehinia et al., 2016) among others. Nevertheless, said computer techniques present some shortcomings related to instability and inconsistency when handling uncertainties.

\subsection{Brazilian Pre-salt}

In late 90s, the Brazilian oil industry started to track down new reserves to perpetuate its production levels. With the development of new exploration technologies (e.g. 4D seismic) and after sedulous searching operations, the pre-salt layer oil was discovered in 2006-2007 by Petróleo Brasileiro S.A. (Petrobras) (Johann \& Monteiro, 2016). Such milestone has impacted the Country's economic and political spheres over the past decade due to its potential to lead the petroleum industry towards a significant development.

The pre-salt layer is located in the Brazilian exclusive economic zone. It encompasses several oil reserves situated up to $300 \mathrm{~km}$ from the coast with different depths between 5,000 and 6,000 meters below sea level; in ultra-deep water (about 2,000 meters); and under a thick salt layer (up to 2,000 meters) (Magalhães \& Domingues, 2014; Kutas, 2015), as illustrated in Figure 4.

The total oil volume in such an area is estimated at about 80 billion barrels, which could make Brazil one of the world's biggest holders of oil reserves (Magalhães \& Domingues, 2014). In fact, the presalt region is comprised of various accumulations, among which the Campos Basin stands out as the first discovery and the main sedimentary region from the Brazilian coastline to be explored. It has a total area of approximately 100,000 square kilometers and currently accounts for $42 \%$ of the total oil production in Brazil (Pré-Sal Petróleo S.A., 2019).

The exploration of the pre-salt region is not only unprecedented but also challenging due to the unfavorable natural conditions. To overcome technical difficulties, it is a must to employ highly experienced professionals, use advanced technologies, and acquire a vast practical knowledge about the area. In this regard, scientific studies play an important role in providing the information needed to develop new strategies towards progress.

\section{METHODS}

Various studies regarding the development and/or evaluation of PVT correlations have been published, which evidence the significance of these data to the oil industry. However, most of these 
Table 2. Range of applicability for solution gas-oil ratio correlations ${ }^{b}$.

\begin{tabular}{lllll}
\hline Author & $\mathrm{T}\left({ }^{\circ} \mathrm{F}\right)$ & $\mathrm{P}(\mathrm{psi})$ & $\gamma_{\mathrm{o}}$ & $\mathrm{V}_{\mathrm{g}}$ \\
\hline Standing (1947) & $100-258$ & $20-1425$ & $0.72-0.96$ & $0.59-0.95$ \\
Glasø (1980) & $80-280$ & $90-2637$ & $0.79-0.92$ & $0.65-1.28$ \\
Vazquez and Beggs (1980) & $75-294$ & $0-2199$ & $0.74-0.96$ & $0.51-1.35$ \\
Ostermann and Owolabi (1983) & $122-180$ & $515-1802$ & $0.84-0.90$ & $0.85-1.09$ \\
Al-Marhoun (1985) & $74-240$ & $26-1602$ & $0.80-0.94$ & $0.75-1.37$ \\
Obomanu and Okpobiri (1987) & $123-190$ & $73-2529$ & $0.81-0.97$ & $0.56-0.93$ \\
Farshad et al. (1992) & $95-260$ & $6-1645$ & $0.80-0.95$ & $0.66-1.7$ \\
Hasan et al. (1993) & - & - & - & - \\
Macary and El-Batanoney (1993) & $130-290$ & $200-1200$ & $0.82-0.90$ & $0.7-1.00$ \\
Petrosky and Farshad (1993) & $114-288$ & $217-1406$ & $0.80-0.96$ & $0.58-0.85$ \\
Kartoatmodjo and Schmidt (1994) & $75-320$ & $0-2890$ & $0.74-0.97$ & $0.38-1.17$ \\
Elsharkawy and Alikhan (1997) & $130-250$ & $39-1586$ & $0.81-0.95$ & $0.66-1.27$ \\
Levitan and Murtha (1999) & $60-250$ & - & $0.70-1.00$ & $0.60-0.90$ \\
Al-Shammasi (2001) & $74-342$ & $32-7127$ & $0.73-1.03$ & $0.51-3.44$ \\
Dindoruk and Christman (2004) & $117-276$ & $926-12230$ & $0.83-0.87$ & $0.76-1.03$ \\
Hemmati and Kharrat (2007) & $78-290$ & $348-5156$ & $0.79-0.94$ & $0.52-1.42$ \\
Mazandarani and Asghari (2007) & $100-250$ & $1000-6000$ & $0.84-0.90$ & $0.87-1.17$ \\
Ikiensikimama and Ajienka (2012) & $122-264$ & $67-6560$ & $0.77-0.97$ & $0.56-1.29$ \\
Arabloo et al. (2015) & $74-361$ & $73-6629$ & $0.75-1.03$ & $0.52-3.44$ \\
Jarrahian et al. (2015) & $68-330$ & $83-6875$ & $0.77-0.97$ & $0.60-1.53$ \\
\hline
\end{tabular}

${ }^{b} \mathrm{~T}$ : Temperature. P: Pressure. $\gamma_{0}$ : Oil gravity. $\gamma_{\mathrm{g}}$ : Gas gravity.

Table 3. Range of applicability for oil formation volume factor correlations ${ }^{c}$.

\begin{tabular}{lllll}
\hline Author & $\mathrm{T}\left({ }^{\circ} \mathrm{F}\right)$ & $\mathrm{R}_{\mathrm{s}}(\mathrm{scf} / \mathrm{STB})$ & $\mathrm{Y}_{\mathrm{o}}$ & $\mathrm{Yg}_{\mathrm{g}}$ \\
\hline Standing (1947) & $100-258$ & $20-1425$ & $0.72-0.96$ & $0.59-0.95$ \\
Glas $\varnothing$ (1980) & $80-280$ & $90-2637$ & $0.79-0.92$ & $0.65-1.28$ \\
Vazquez and Beggs (1980) & $75-294$ & $0-2199$ & $0.74-0.96$ & $0.51-1.35$ \\
Al-Marhoun (1985) & $74-240$ & $26-1602$ & $0.80-0.94$ & $0.75-1.37$ \\
Obomanu and Okpobiri (1987) & $123-190$ & $73-2529$ & $0.81-0.97$ & $0.56-0.93$ \\
Abdul-Majeed and Salman (1988) & $75-290$ & $0-1664$ & $0.74-1.00$ & - \\
Labedi (1990) & $100-306$ & $13-3533$ & $0.79-0.86$ & $0.70-1.47$ \\
Dokla and Osman (1992) & $190-275$ & $181-2266$ & $0.82-0.89$ & $0.80-1.29$ \\
Farshad et al. (1992) & $95-260$ & $6-1645$ & $0.80-0.95$ & $0.66-1.7$ \\
Macary and El-Batanoney (1993) & $130-290$ & $200-1200$ & $0.82-0.90$ & $0.7-1.00$ \\
Omar and Todd (1993) & $125-280$ & $142-1440$ & $0.77-0.89$ & $0.61-1.32$ \\
Petrosky and Farshad (1993) & $114-288$ & $217-1406$ & $0.80-0.96$ & $0.58-0.85$ \\
Kartoatmodjo and Schmidt (1994) & $75-320$ & $0-2890$ & $0.74-0.97$ & $0.38-1.17$ \\
Almehaideb (1997) & $190-306$ & $128-3871$ & $0.79-0.87$ & $0.75-1.12$ \\
Elsharkawy and Alikhan (1997) & $130-250$ & $39-1586$ & $0.81-0.95$ & $0.66-1.27$ \\
El-Banbi et al. (2006) & $186-312$ & $0-8280$ & $0.74-0.85$ & $0.67-1.14$ \\
Karimnezhad et al. (2014) & $59-306$ & $9-3299$ & $0.77-1.03$ & $0.62-1.53$ \\
Sulaimon (2014) & $125-280$ & $142-1440$ & $0.77-0.89$ & $0.04-1.32$ \\
Torabi et al. (2014) & $60-140$ & - & $0.80-1.03$ & - \\
Mahdiani and Kooti (2016) & $100-280$ & $104-1439$ & $0.77-0.90$ & $0.61-1.32$ \\
\hline
\end{tabular}

${ }^{c} \mathrm{~T}$ : Temperature. $R_{s}$ : Solution gas-oil ratio. $\gamma_{0}$ : Oil gravity. $\nu_{g}$ : Gas gravity.

studies are based on restricted criteria that usually depend on specific properties of the given region where the data were retrieved from (RafieeTaghanaki et al., 2013). Therefore, in this study, we compared different correlations to assert which ones best represent the characteristics of the Campos Basin reserves of the Brazilian pre-salt region. The models for the estimation of $R_{s}, B_{0}$, and $\mu_{\mathrm{o}}$ studied on the present study are disclosed in Appendices $A, B$, and $C$, respectively. 
Table 4. Range of applicability for undersaturated oil viscosity correlations ${ }^{d}$.

\begin{tabular}{lllll}
\hline Author & $\mathrm{T}\left({ }^{\circ} \mathrm{F}\right)$ & $\mathrm{P}(\mathrm{psi})$ & $\mathrm{R}_{\mathrm{s}}$ (scf/STB) & $\mathrm{Y}_{\mathrm{o}}$ \\
\hline Beal (1946) & $100-220$ & $1515-5155$ & - & - \\
Kouzel (1965) & - & $407-6000$ & - & - \\
Vazquez and Beggs (1980) & $75-294$ & $141-9515$ & $0-2199$ & $0.74-0.96$ \\
Khan et al. (1987) & $75-240$ & $0-5000$ & $24-1901$ & $0.80-0.97$ \\
Abdul-Majeed et al. (1990) & - & $711-7112$ & $60-1334$ & $0.78-0.97$ \\
Kartoatmodjo and Schmidt (1991) & - & $25-6015$ & - & $0.74-0.97$ \\
Labedi (1992) & $100-306$ & $60-6358$ & $13-3533$ & $0.79-0.85$ \\
De Ghetto et al. (1994) & $80-342$ & $227-15289$ & $9-3299$ & $0.92-1.03$ \\
Petrosky and Farshad (1995) & - & $1585-10235$ & - & $0.80-0.90$ \\
Almehaideb (1997) & $190-306$ & $501-4822$ & $128-3871$ & $0.79-0.87$ \\
Elsharkawy and Alikhan (1999) & - & $1287-10000$ & $10-3600$ & $0.79-0.94$ \\
Dindoruk and Christman (2004) & $121-276$ & $926-12230$ & $133-3050$ & $0.83-0.95$ \\
Hossain et al. (2005) & - & $300-3400$ & - & $0.92-1.02$ \\
Bergman and Sutton (2006) & $32-425$ & $100-25000$ & $0-4631$ & $0.73-1.03$ \\
Isehunwa et al. (2006) & $124-289$ & $284-9392$ & $43-19149$ & $0.80-0.94$ \\
Abedini et al. (2010) & $134-272$ & $1325-3485$ & $647-1542$ & $0.82-0.96$ \\
Hemmati-Sarapardeh et al. (2013) & $205-255$ & $730-12500$ & - & $0.79-0.89$ \\
Taghizadeh and Eftekhari (2014) & - & $940-6015$ & $315-1558$ & - \\
Al-Marhoun (2015) & - & $0-5000$ & $<2000$ & $>0.80$ \\
Alqahtani et al. (2018) & - & $400-3495$ & - & - \\
\hline
\end{tabular}

${ }^{d} \mathrm{~T}$ : Temperature. P: Pressure. $\mathrm{R}_{\mathrm{s}}$ : Solution gas-oil ratio. $\mathrm{\gamma}_{\mathrm{o}}$ : Oil gravity.

Table 5. Data ranges considered in this work (according to Elias \& Trevisan, 2016) ${ }^{e}$.

\begin{tabular}{lllll}
\hline Parameter & $\mathrm{T}\left({ }^{\circ} \mathrm{F}\right)$ & $\mathrm{P}(\mathrm{psi})$ & $\gamma_{\mathrm{o}}$ & $\gamma_{\mathrm{g}}$ \\
\hline $\mathrm{R}_{\mathrm{s}}$ & $68-204$ & $711-5759.1$ & $0.71-0.84$ & $0.93-1.13$ \\
$\mathrm{~B}_{\mathrm{o}}$ & $68-204$ & $711-5759.1$ & $0.71-0.84$ & $0.93-1.13$ \\
$\mu_{\mathrm{o}}$ & $68-204$ & $5759.1-9243.0$ & $0.71-0.84$ & $0.93-1.13$ \\
\hline${ }^{e} \mathrm{~T}:$ Temperature. P: Pressure. $\gamma_{\mathrm{o}}$ : Oil gravity. $\gamma_{\mathrm{g}}$ : Gas gravity. & \multicolumn{3}{l}{}
\end{tabular}

Yet, one should note that all correlations may be applicable only depending on specific parameters. For instance, the equations evaluated in this paper can only be used for the ranges of temperature, pressure, oil and gas gravities disclosed in Tables 2, 3, and 4, respectively. This is due to the fact that such prediction models were originally developed through experimental data that were measured under those specific conditions. The same applies to Elias and Trevisan's (2016) study, which was based on the data ranges shown in Table 5 . In this regard, it is expected that correlations using ranges of parameters that are different from the respective ranges considered by said authors may provide inaccurate or erroneous results. In addition to said tables, Figures 5, 6, and 7 illustrate the comparison between the validity ranges of the different correlations, and the ranges corresponding to the experimental data used by the referenced authors.
The disclosed correlations were compared to the experimental data presented by Elias and Trevisan (2016), who recombined dead oil and synthetic gas to obtain an original pre-salt live oil sample. Although the authors stated that they had analyzed oil samples found in Brazilian pre-salt reserves in the region of Campos Basin, it seems that they have opted for not providing further information regarding the respective oil fields due to confidentiality purposes. However, one may infer that the experiments were carried out using oil samples that are representative of such a region.

The qualitative comparison was carried out by means of crossplots regressions, whereas the quantitative analysis was performed through the calculation of the Average Absolute Relative Error (AARE), Root Mean Square Error (RMSE), and Standard Error of Estimate (SEE), as shown in 
Equations 3, 4, and 5, respectively (Hossain et al., 2005; Rafiee-Taghanaki et al., 2013).

$\operatorname{ARRE}=\frac{100}{\mathrm{n}} \cdot \sum_{\mathrm{i}=1}^{\mathrm{n}}\left(\left|\frac{\mathrm{X}_{\text {calc }}-\mathrm{X}_{\text {exp }}}{\mathrm{X}_{\mathrm{exp}}}\right|_{i}\right)$

$\operatorname{RMSE}=\left[\frac{1}{\mathrm{n}} \sum_{\mathrm{i}=1}^{\mathrm{n}}\left(\mathrm{X}_{\mathrm{calc}}-\mathrm{X}_{\mathrm{exp}}\right)_{i}^{2}\right]^{0.5}$

$\mathrm{SEE}=\left[\sum_{\mathrm{i}=1}^{\mathrm{n}}\left(\mathrm{X}_{\text {calc }}-\mathrm{X}_{\text {exp }}\right)_{i}^{2} /(n-v-1)\right]^{0.5}$

Where $n$ is the number of experimental data points, $X_{\text {calc }}$ refers to the calculated value, $X_{\text {exp }}$ corresponds to the experimental result, and $v$ denotes the number of independent variables.

\section{RESULTS AND DISCUSSION}

Statistical results comparing $R_{s}$ correlations are quantitatively given in Table 6. An analysis of the results shows that Al-Shammasi's (2001) correlation predicted the closest values with regard to Elias and Trevisan's (2016) data, having an AARE of $13.7110 \%$, a RMSE of 68.5537 , and a SEE of 102.8305. Elsharkawy and Alikhan (1997), Arabloo et al. (2015), and Jarrahian et al.'s (2015) models also presented good performances. On the other hand, Obomanu and Okpobiri's (1987) model showed to be the most inadequate for estimating the solution gas-oil ratio for the Campos Basin oil samples, since it presented an AARE, a RMSE, and a SEE as high as $81.9856 \%, 764.8087$, and 1147.2130 , respectively. Levitan and Murtha's (1999) correlation also proved to be quite inaccurate, having an AARE of $55.1526 \%$, a RMSE of 478.4374 , and a SEE of 717.6561.

The accuracy of Al-Shammasi (2001), Arabloo et al. (2015), and Jarrahian et al.'s (2015) models relates to their respective data ranges, which encompass Elias and Trevisan's (2016). In fact, as we can observe from Figure 5, the latter ranges of temperature, pressure, oil and gas gravities fall within the respective ranges of said correlations. Nevertheless, it is imperative to note that the ranges considered by Obomanu and Okpobiri's (1987) equation are quite different from the ones used by Elias and Trevisan (2016). Hence, the former cannot be deemed representative of the (a)

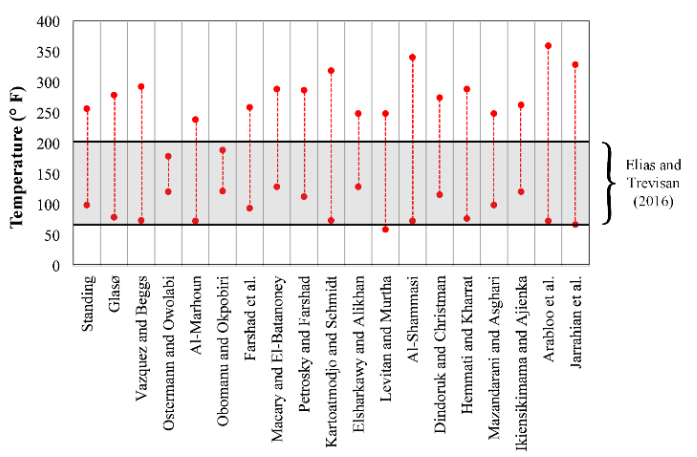

(b)

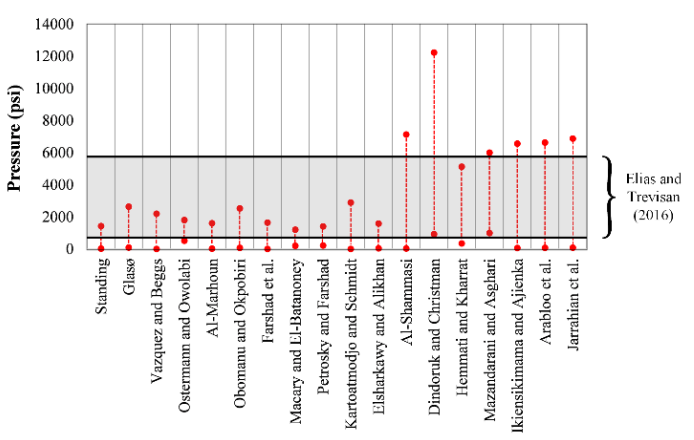

(c)

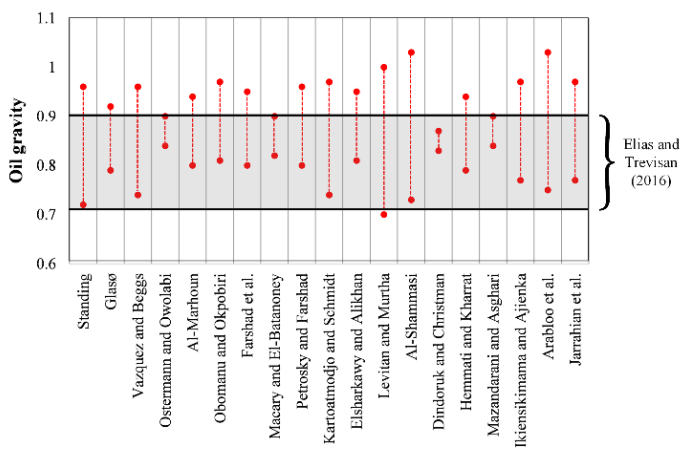

(d)

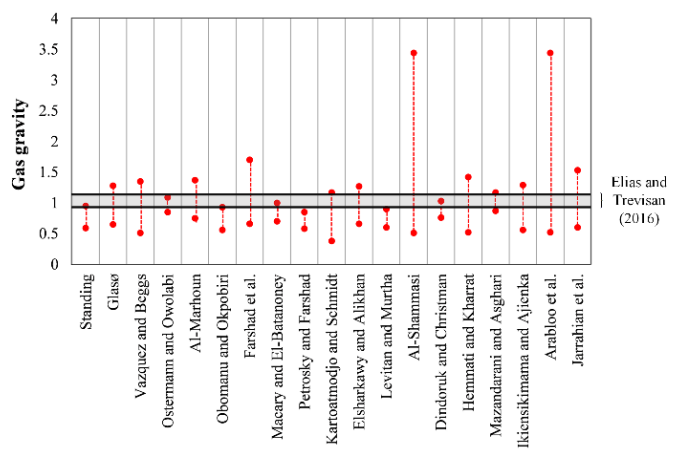

Figure 5. Ranges for $R_{s}$ correlations: (a) Temperature;

(b) Pressure; (c) Oil gravity; and (d) Gas gravity.

Campos Basin data evaluated by the latter.

The results of the $B_{0}$ correlations, in turn, are shown in Table 7. We note that Al-Marhoun's (1985) correlation can be considered to be the most representative since it estimated the closest values to Elias and Trevisan's (2016) results, having 
(a)

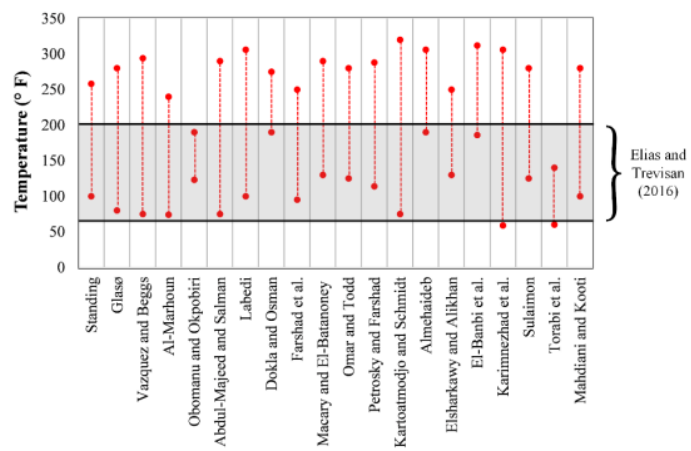

(b)

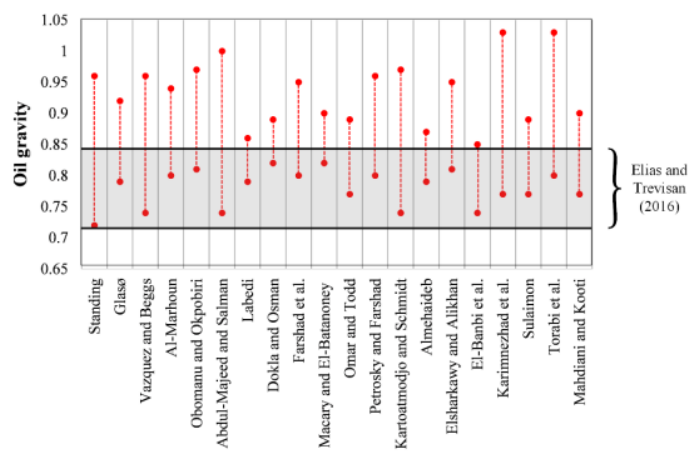

(c)

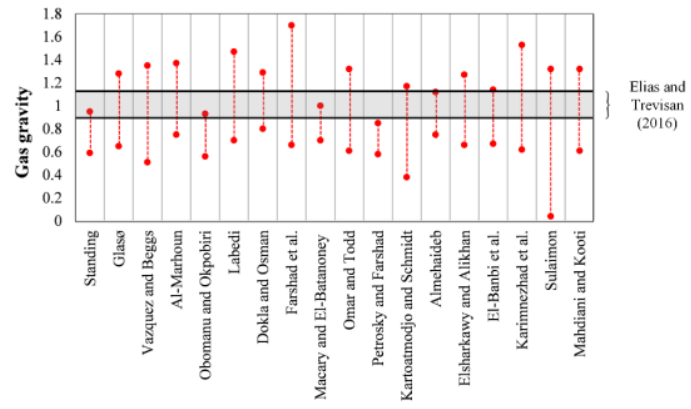

Figure 6. Ranges for $\mathrm{B}_{\mathrm{o}}$ correlations: (a) Temperature; (b) Oil gravity; and (c) Gas gravity.

an AARE, a RMSE, and a SEE as low as $0.4956 \%$, 0.0116 , and 0.0174 , respectively.

An analysis of Table 7 points out that models presented by Al-Marhoun (1985), Petrosky and Farshad (1993), Vazquez and Beggs (1980), Farshad et al. (1992), and Almehaideb (1997) also showed good performances. Once more, Obomanu and Okpobiri's (1987) equation showed the worst prediction of performance, since it has the highest AARE (66.2463\%), RMSE (1.0617), and SEE (1.5926). Other correlations that may be deemed quite inaccurate for $B_{0}$ estimation are Macary and El-Batanoney's (1993) (AARE of 50.3572\%, RMSE of 0.7562 , and SEE of 1.1343) and Elsharkawy and Alikhan's (1997) (AARE of 51.9248\%, RMSE of 0.8703 , and SEE of 1.3055).

Comparably to the analysis of $R_{s}$ models, the (a)

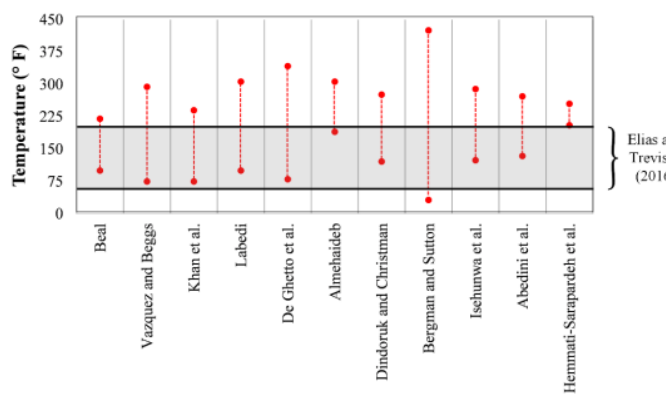

(b)

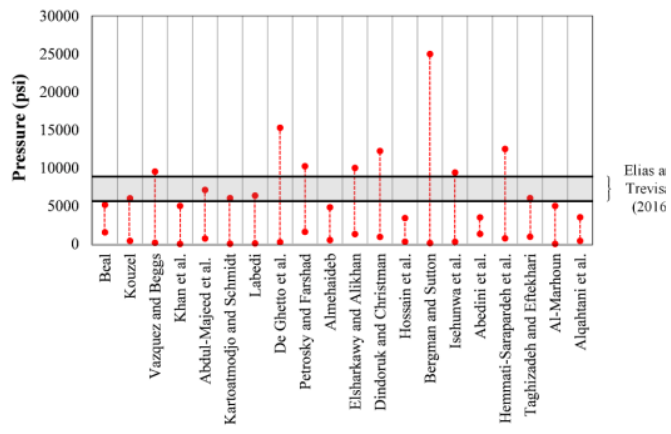

(c)

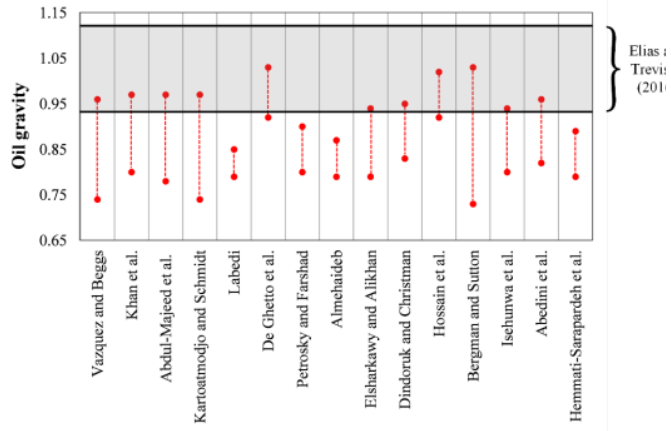

Figure 7. Ranges for $\mu_{\mathrm{o}}$ correlations: (a) Temperature; (b) Pressure; and (c) Oil gravity.

accuracy of Vazquez and Beggs (1980), AlMarhoun (1985), Farshad et al. (1992), and Almehaideb's (1997) models can be associated with their respective data ranges, which encompass the ranges considered by Elias and Trevisan's (2016) work. The ranges considered by Obomanu and Okpobiri (1987), Macary and ElBatanoney (1993), and Elsharkawy and Alikhan (1997) are significantly different than those studied by Elias and Trevisan (2016) and, therefore, are not representative of the latter's data.

Finally, the results of the $\mu_{\mathrm{o}}$ correlations are disclosed in Table 8. Based on these results we can state that Beal's (1946) model has the best performance, having an AARE, a RMSE, and a SEE as low as 0.4557\%, 0.0034, and 0.0051, respectively. In addition, Almehaideb (1997) and Al-Marhoun's (2015) correlations also proved to be 
Table 6. Statistical results for solution gas-oil ratio correlations.

\begin{tabular}{llll}
\hline Author & AARE & RMSE & SEE \\
\hline Standing (1947) & $19.6280 \%$ & 124.7095 & 187.0642 \\
Glasø (1980) & $28.4030 \%$ & 199.2099 & 298.8148 \\
Vazquez and Beggs (1980) & $31.9009 \%$ & 267.7336 & 401.6003 \\
Ostermann and Owolabi (1983) & $46.3772 \%$ & 468.4108 & 702.6162 \\
Al-Marhoun (1985) & $23.3597 \%$ & 124.7855 & 187.1783 \\
Obomanu and Okpobiri (1987) & $81.9856 \%$ & 764.8087 & 1147.2130 \\
Farshad et al. (1992) & $43.3295 \%$ & 602.2207 & 903.3311 \\
Hasan et al. (1993) & $26.5825 \%$ & 183.2466 & 274.8699 \\
Macary and El-Batanoney (1993) & $27.9560 \%$ & 273.3704 & 410.0556 \\
Petrosky and Farshad (1993) & $26.3081 \%$ & 206.8251 & 310.2376 \\
Kartoatmodjo and Schmidt (1994) & $27.3881 \%$ & 250.7344 & 376.1016 \\
Elsharkawy and Alikhan (1997) & $14.5985 \%$ & 82.9026 & 124.3540 \\
Levitan and Murtha (1999) & $55.1526 \%$ & 478.4374 & 717.6561 \\
Al-Shammasi (2001) & $13.7110 \%$ & 68.5537 & 102.8305 \\
Dindoruk and Christman (2004) & $26.4544 \%$ & 213.1236 & 319.6854 \\
Hemmati and Kharrat (2007) & $19.8919 \%$ & 155.5240 & 233.286 \\
Mazandarani and Asghari (2007) & $23.1238 \%$ & 120.0571 & 180.0857 \\
Ikiensikimama and Ajienka (2012) & $40.3765 \%$ & 469.0397 & 703.5595 \\
Arabloo et al. (2015) & $15.3604 \%$ & 143.5444 & 215.3166 \\
Jarrahian et al. (2015) & $15.8614 \%$ & 87.4754 & 131.213 \\
\hline
\end{tabular}

Table 7. Range of applicability for oil formation volume factor correlations.

\begin{tabular}{llll}
\hline Author & AARE & RMSE & SEE \\
\hline Standing (1947) & $3.3561 \%$ & 0.0649 & 0.0974 \\
Glasø (1980) & $2.7454 \%$ & 0.0461 & 0.0692 \\
Vazquez and Beggs (1980) & $1.8727 \%$ & 0.0390 & 0.0585 \\
Al-Marhoun (1985) & $0.4956 \%$ & 0.0116 & 0.0174 \\
Obomanu and Okpobiri (1987) & $66.2463 \%$ & 1.0617 & 1.5926 \\
Abdul-Majeed and Salman (1988) & $6.0462 \%$ & 0.0942 & 0.1413 \\
Labedi (1990) & $2.5189 \%$ & 0.0482 & 0.0723 \\
Dokla and Osman (1992) & $27.8514 \%$ & 0.3964 & 0.5945 \\
Farshad et al. (1992) & $1.5888 \%$ & 0.0240 & 0.0360 \\
Macary and El-Batanoney (1993) & $50.3572 \%$ & 0.7562 & 1.1343 \\
Omar and Todd (1993) & $18.7229 \%$ & 0.3017 & 0.4525 \\
Petrosky and Farshad (1993) & $0.8511 \%$ & 0.0140 & 0.0210 \\
Kartoatmodjo and Schmidt (1994) & $28.3971 \%$ & 0.4525 & 0.6788 \\
Almehaideb (1997) & $1.4679 \%$ & 0.0285 & 0.0428 \\
Elsharkawy and Alikhan (1997) & $51.9248 \%$ & 0.8703 & 1.3055 \\
El-Banbi et al. (2006) & $15.5575 \%$ & 0.2965 & 0.4448 \\
Karimnezhad et al. (2014) & $2.2410 \%$ & 0.0371 & 0.0556 \\
Sulaimon (2014) & $16.5538 \%$ & 0.2645 & 0.3967 \\
Torabi et al. (2014) & $3.2751 \%$ & 0.0522 & 0.0784 \\
Mahdiani and Kooti (2016) & $4.3533 \%$ & 0.0761 & 0.1141 \\
\hline
\end{tabular}

representative of Elias and Trevisan's (2016) data, since their statistical errors were quite low. Elsharkawy and Alikhan's (1999) equation, however, can be deemed the worst model for predicting the under-saturated oil viscosity of the Campos Basin samples due to its significant errors (AARE of $16.2215 \%$, RMSE of 0.1468 , and SEE of $0.2203)$. Other correlations that, due to large errors, may not be considered as representatives for $\mu_{\mathrm{o}}$ estimation are Hossain et al. (2005), Isehunwa et al. (2006), and Abedini et al.'s (2010).

One can verify that, in the case of $\mu_{0}$, the performance of PVT models does not seem to be strictly dependent on their respective data ranges. Figure 7 shows that the aforementioned correlations, including the best ones, have different ranges from the ones proposed by Elias and 
Table 8. Statistical results for under-saturated oil viscosity correlations.

\begin{tabular}{llll}
\hline Author & AARE & RMSE & SEE \\
\hline Beal (1946) & $0.4557 \%$ & 0.0034 & 0.0051 \\
Kouzel (1965) & $2.9965 \%$ & 0.0284 & 0.0426 \\
Vazquez and Beggs (1980) & $2.1124 \%$ & 0.0194 & 0.0292 \\
Khan et al. (1987) & $4.1631 \%$ & 0.0396 & 0.0594 \\
Abdul-Majeed et al. (1990) & $2.0588 \%$ & 0.0184 & 0.0276 \\
Kartoatmodjo and Schmidt (1991) & $4.2633 \%$ & 0.0403 & 0.0604 \\
Labedi (1992) & $2.3359 \%$ & 0.0223 & 0.0335 \\
De Ghetto et al. (1994) & $4.0243 \%$ & 0.0355 & 0.0533 \\
Petrosky and Farshad (1995) & $3.7108 \%$ & 0.0326 & 0.0490 \\
Almehaideb (1997) & $0.6473 \%$ & 0.0055 & 0.0082 \\
Elsharkawy and Alikhan (1999) & $16.2215 \%$ & 0.1468 \\
Dindoruk and Christman (2004) & $2.3349 \%$ & 0.0185 & 0.2203 \\
Hossain et al. (2005) & $4.9473 \%$ & 0.0439 & 0.0278 \\
Bergman and Sutton (2006) & $2.4147 \%$ & 0.0188 \\
Isehunwa et al. (2006) & $4.9385 \%$ & 0.0470 & 0.0659 \\
Abedini et al. (2010) & $6.4906 \%$ & 0.0580 & 0.0282 \\
Hemmati-Sarapardeh et al. (2013) & $2.6063 \%$ & 0.0248 & 0.0706 \\
Taghizadeh and Eftekhari (2014) & $3.2091 \%$ & 0.0304 & 0.0870 \\
Al-Marhoun (2015) & $0.6062 \%$ & 0.0053 & 0.0372 \\
Alqahtani et al. (2018) & $3.2577 \%$ & 0.0263 & 0.0457 \\
\hline
\end{tabular}

Trevisan (2016). It is worth highlighting that, in this article, we aimed at comparing the behavior of generic PVT correlations when estimating fluid properties of the Campos Basin fluid samples, instead of calibrating the parameters and/or developing specific models.

It is worth pointing out that the correlations that best predicted $R_{s}$ for the Campos Basin oil samples were developed originally for different fields. For instance, Al-Shammasi (2001), Arabloo et al. (2015), and Jarrahian et al. (2015) carried out their evaluation on the basis of global data sets, while Elsharkawy and Alikhan (1997) evaluated samples from Kuwait. In relation to $B_{0}$, Al-Marhoun (1985) and Almehaideb (1997) analyzed experimental data from the Middle East region, whereas Petrosky and Farshad (1993) based their analysis on samples obtained in the Gulf of Mexico area. Farshad et al. (1992) and Vazquez and Beggs (1980), in turn, used oil samples from Colombian fields and global data sets, respectively. Finally, regarding the predictions of $\mu_{0}$, Beal's (1946) model was based on data retrieved in the United States, while Almehaideb (1997) and Al-Marhoun (2015) developed their equations on the basis of samples from the United Arab Emirates. This corroborates Danesh's (1998) statement concerning the fact that petroleum properties do not depend on the reserve location itself, but instead on fluid composition and reservoir conditions. Hence, it is possible that said references evaluated data sets with compositions similar to the ones found for Elias and Trevisan's (2016) samples.

The qualitative analysis for the comparison of $\mathrm{R}_{\mathrm{s}}, \mathrm{B}_{\mathrm{o}}$, and $\mu_{\mathrm{o}}$ correlations with Elias and Trevisan's (2016) data was then performed through the crossplots illustrated in Figures 8, 9, and 10, respectively. Regarding the solution gas-oil ratio, most models resulted in under-predicted data, while Farshad et al. (1992), Macary and ElBatanoney (1993), Ikiensikimama and Ajienka (2012), and Arabloo et al. (2015) over-estimated the values for higher pressures. In relation to the oil formation volume factor, in turn, Abdul-Majeed and Salman (1988), Kartoatmodjo and Schmidt (1994), Omar and Todd (1993), El-Banbi et al. (2006), and Sulaimon (2014) under-predicted the experimental data, whereas Dokla and Osman (1992), Elsharkawy and Alikhan (1997), Obomanu and Okpobiri (1987), Macary and El-Batanoney (1993), and Mahdiani and Kooti (2016) presented over-estimated results. Finally, with regard to under-saturated oil viscosity, Abdul-Majeed et al. (1990), Kartoatmodji and Schmidt (1991), Labedi (1992), and Hemmati-Sarapardeh et al. (2013) provided under-predicted results, while Kouzel (1965), Khan et al. (1987), De Ghetto et al. (1994), Petrosky and Farshad (1995), Elsharkawy and Alikhan (1999), Hossain et al. (2005), Isehunwa et al. (2006), and Abedini et al.'s (2010) models resulted in over-predicted data. 

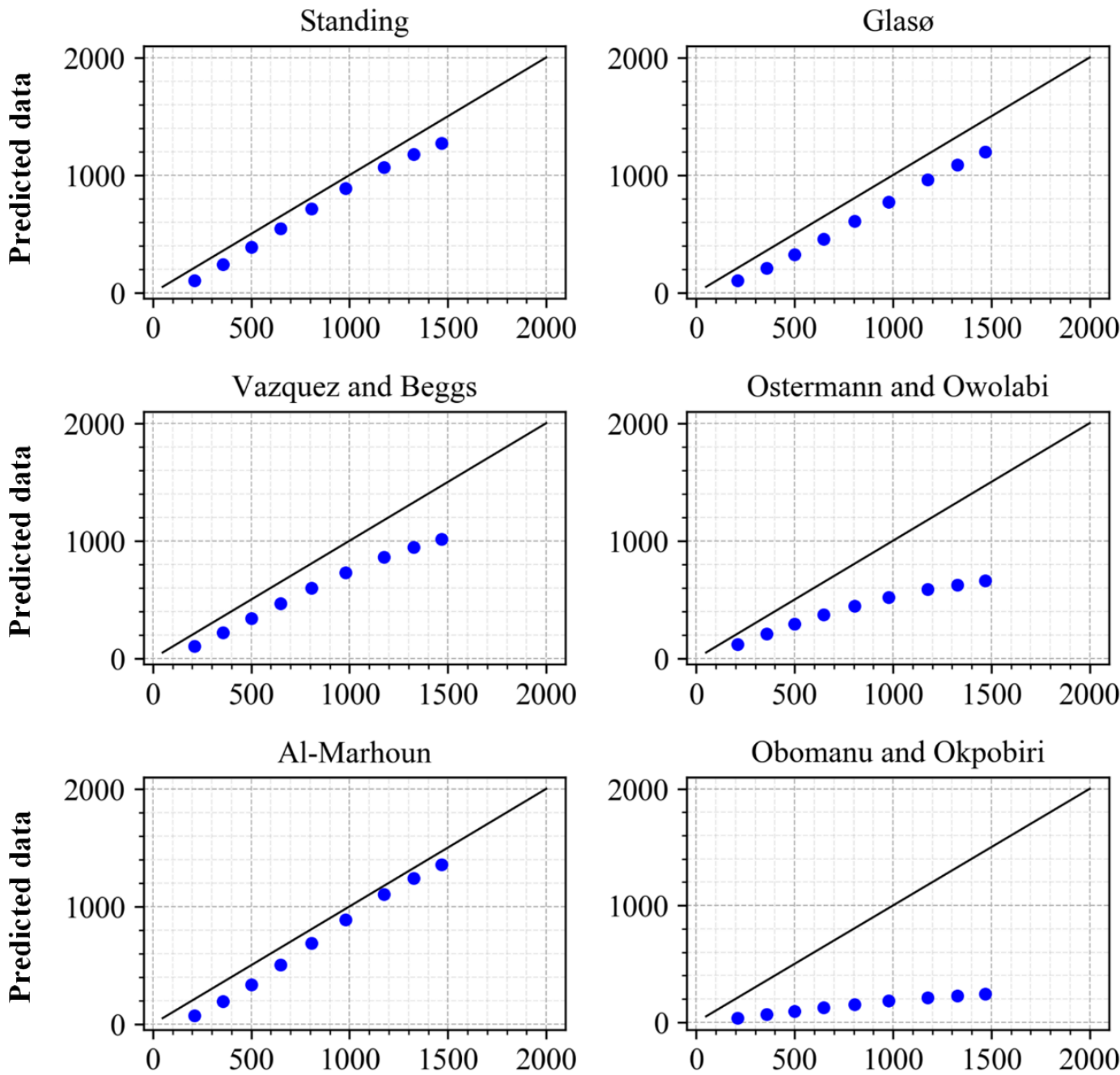

Farshad et al.

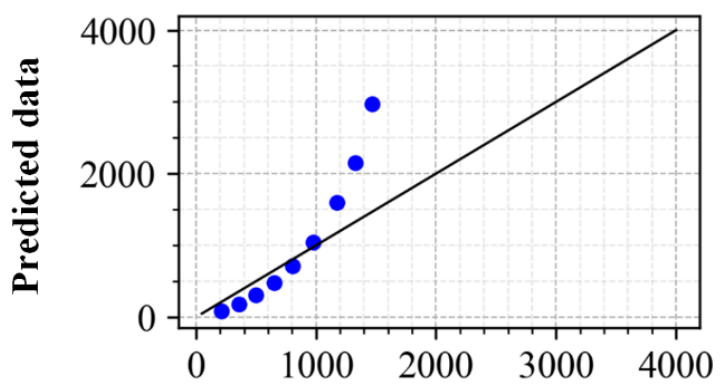

Hasan et al.
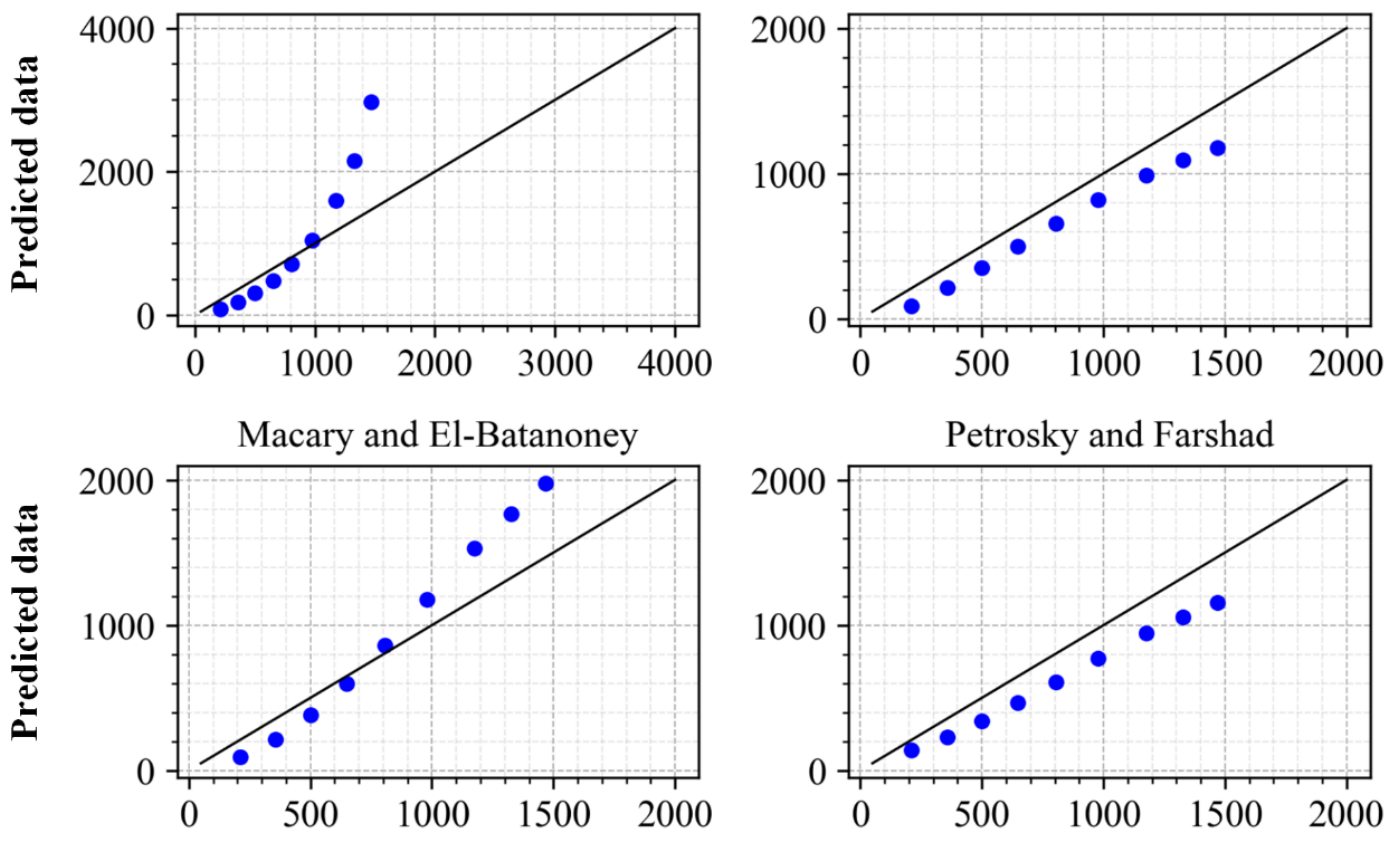

Experimental data

Experimental data

Figure 8. Crossplots for $R_{s}$ correlations (Part 1). 

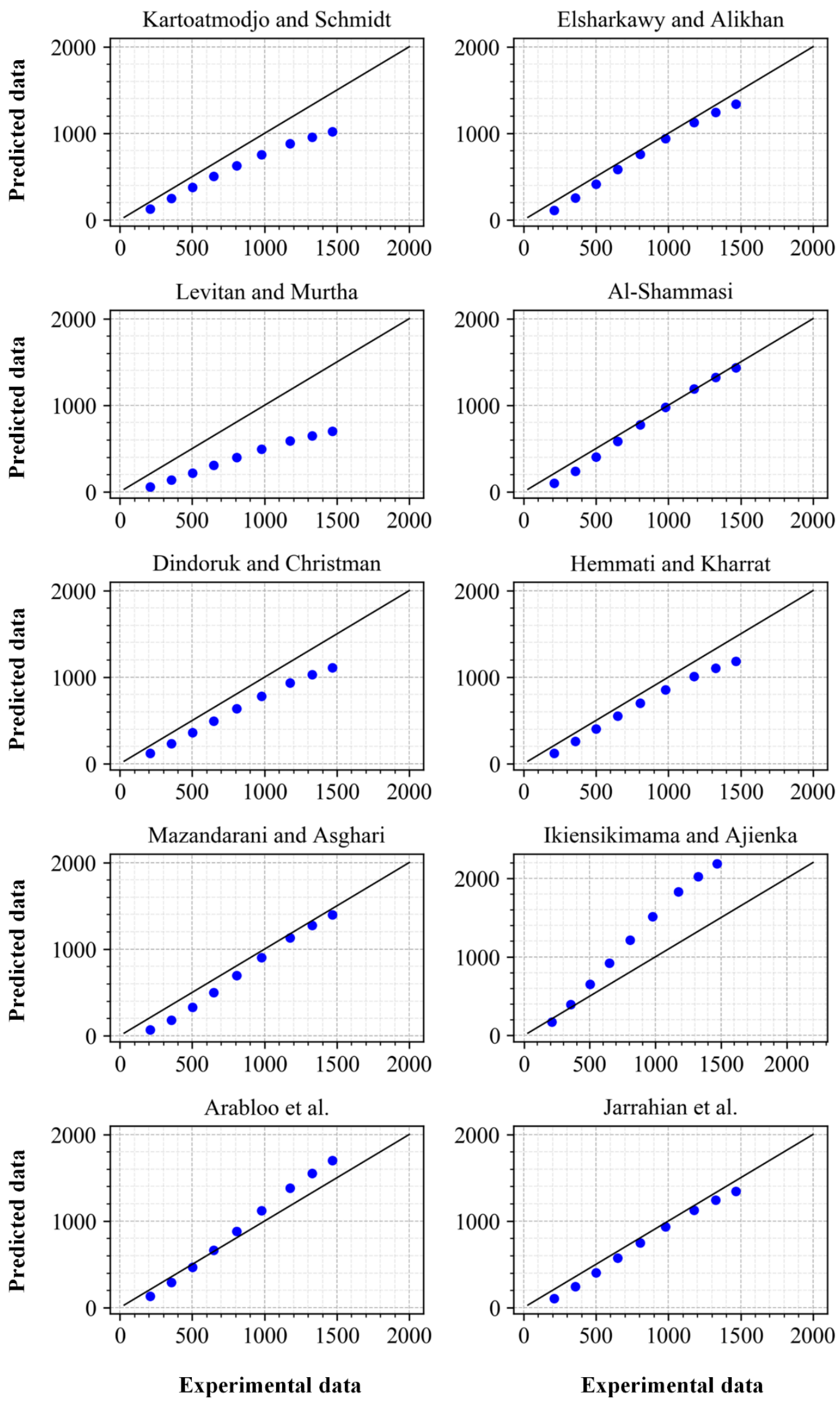

Figure 8. Crossplots for $R_{s}$ correlations (Part 2). 

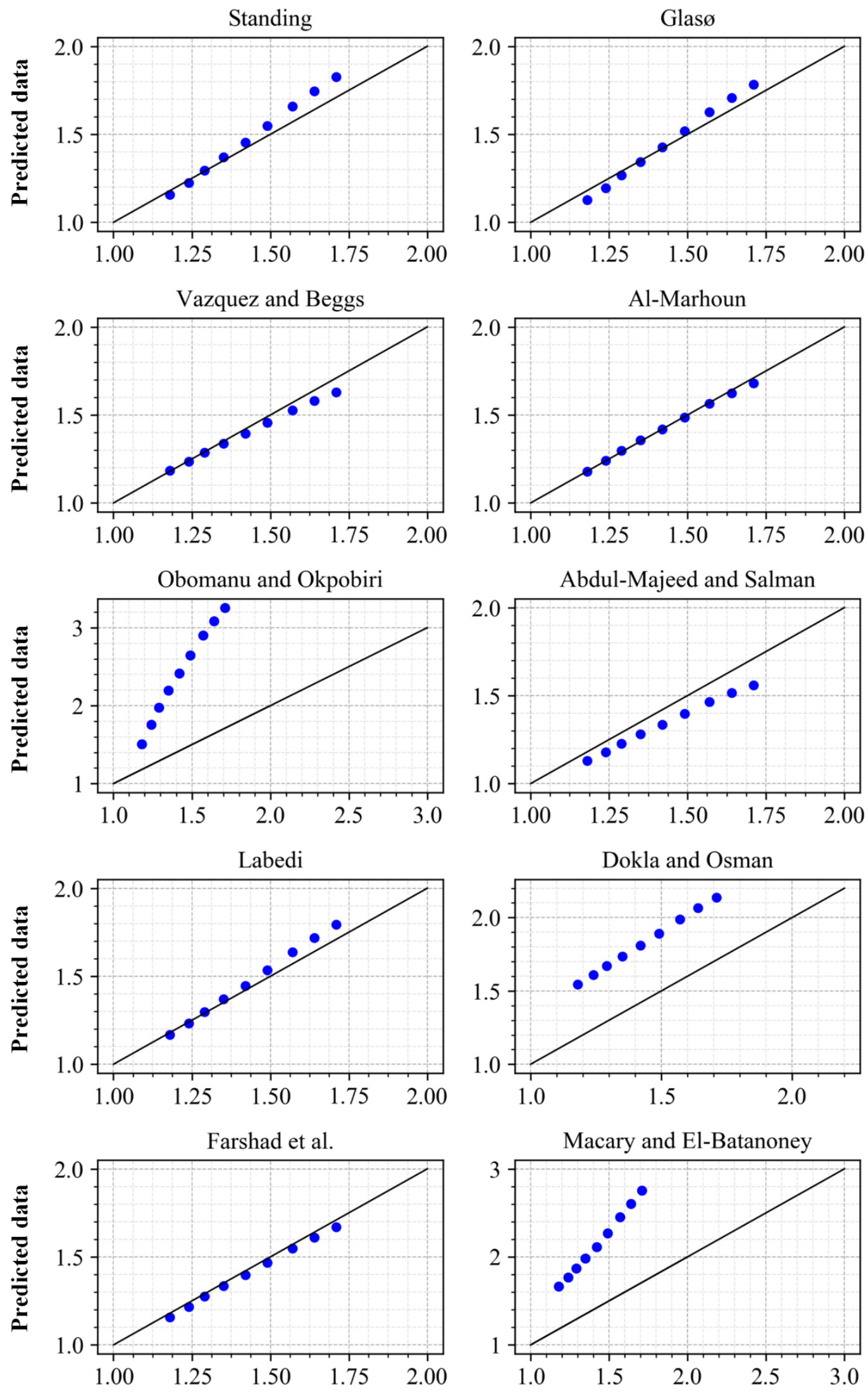

Experimental data

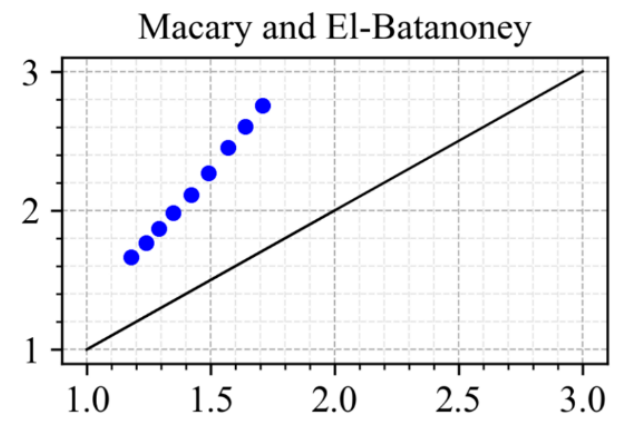

Experimental data

Figure 9. Crossplots for $\mathrm{B}_{\mathrm{o}}$ correlations (Part 1). 

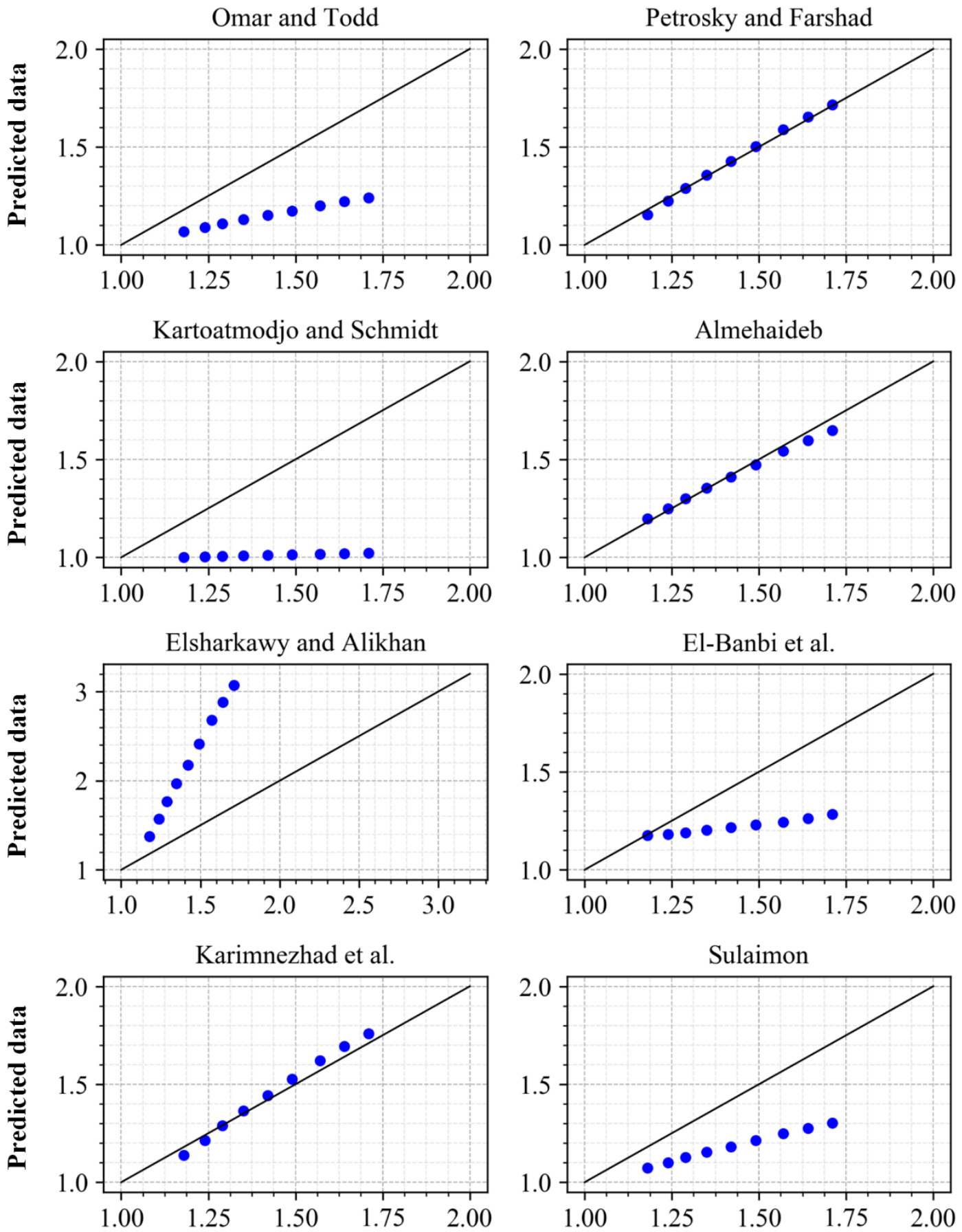

Torabi et al.

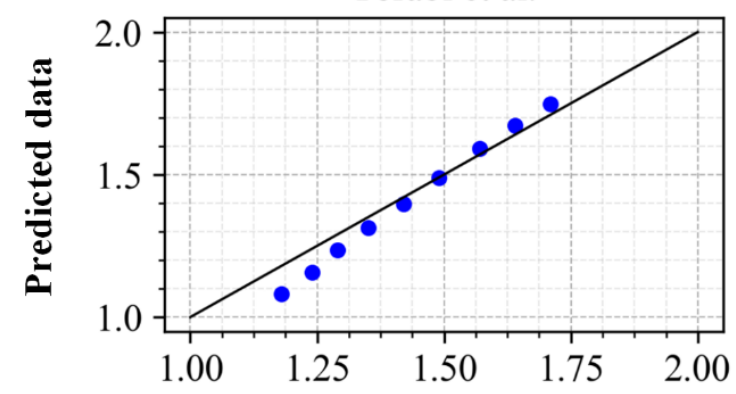

Experimental data

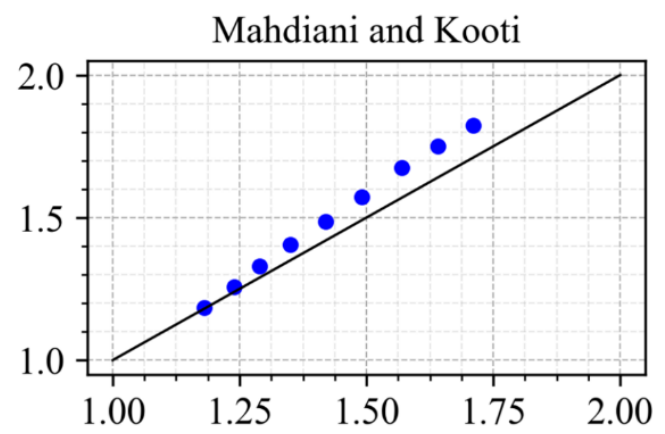

Experimental data

Figure 9. Crossplots for $\mathrm{B}_{\mathrm{o}}$ correlations (Part 2). 

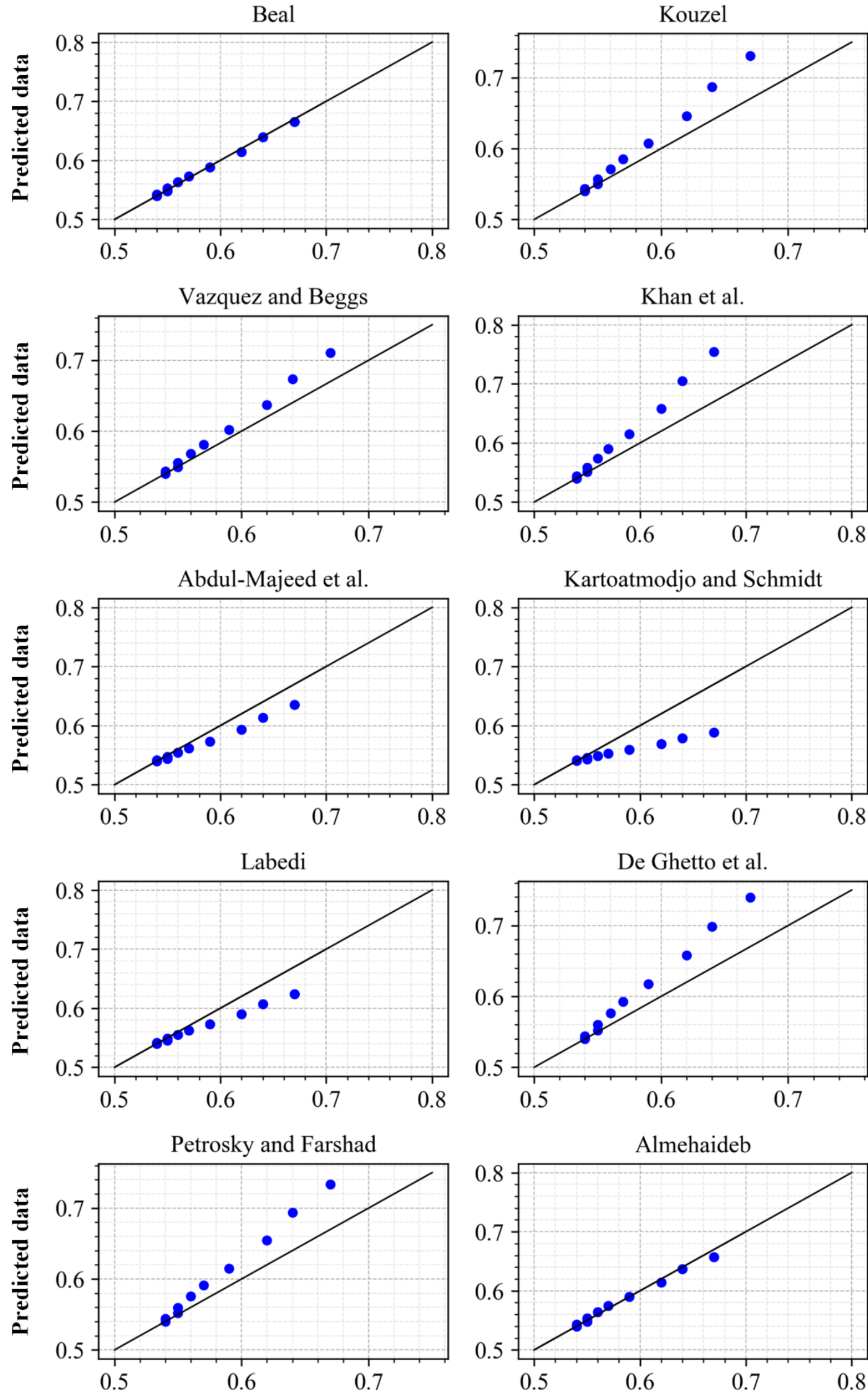

Experimental data

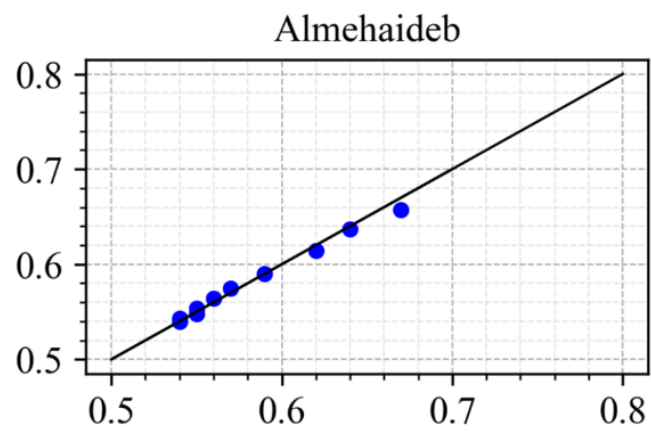

Experimental data

Figure 10. Crossplots for $\mu_{\mathrm{o}}$ correlations (Part 1). 

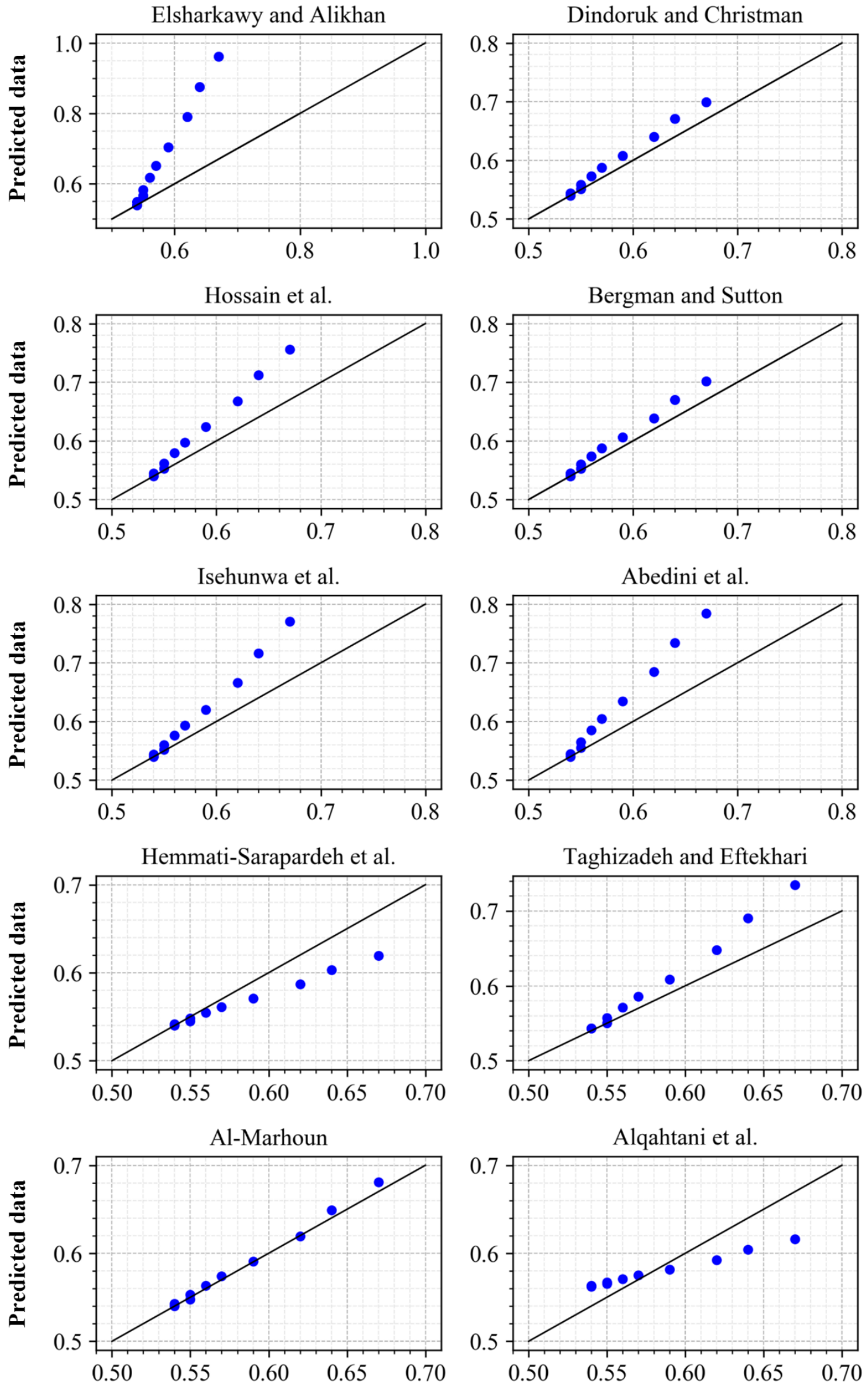

Experimental data

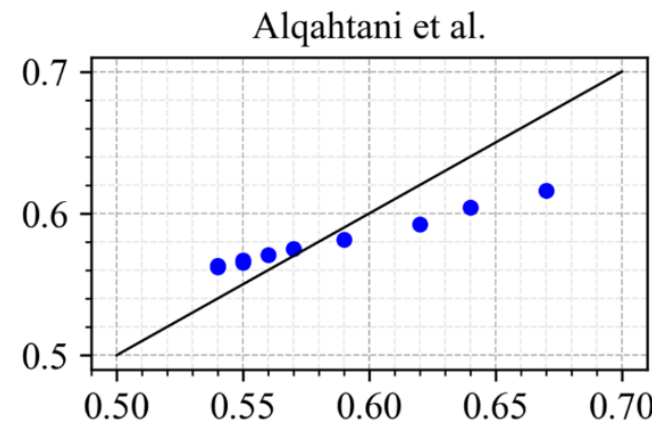

Experimental data

Figure 10. Crossplots for $\mu_{\mathrm{o}}$ correlations (Part 2). 
In accordance with the quantitative results disclosed in Tables 6, 7, and 8, we verify that AlMarhoun (1985), Al-Shammasi (2001) and Beal's (1946) correlations clearly are almost perfectly fit onto their respective equality reference lines. Therefore, they can be considered as the best models for estimating $R_{s}, B_{o}$, and $\mu_{o}$ of oils from the Campos Basin considered by Elias and Trevisan (2016), respectively. Although current practices frequently use computational methods for performing calculations, simple equation forms may be preferred. In this regard, Elsharkawy and Alikhan's (1997) model may be selected for $R_{s}$ estimation, while Almehaideb's (1997) correlation may be used to provide good and easy estimates for $\mathrm{B}_{\mathrm{o}}$. In terms of $\mu_{\mathrm{o}}$ correlations, Beal's (1946) model may be already deemed the simplest.

It is noteworthy that most of the correlations studied in this paper presented large statistical errors because the analysis of the present work was carried out in a relatively limited range of data. Such errors could be reduced through the development of specific models for pre-salt fluids. More specifically, the development of models for oils from the Campos Basin region - which would be performed by calibrating the parameters of the respective equations. However, a more substantial amount of experimental data would be necessary.

In addition, a possible reason for obtaining such large errors may be related to the high contents of $\mathrm{CO}_{2}$ in pre-salt reserves, which vary from about $8 \%$ (e.g. Tupi reserve, according to Beltrão et al., 2009) to approximately $44 \%$ (e.g. Libra field, according to Arinelli et al., 2015). The presence of carbon dioxide in oil reservoirs influences strongly the phase equilibria of such mixtures since $\mathrm{CO}_{2}$ is soluble with crude oil (much more than other conventional gases), especially when the former's density increases due to compression. As discussed by Mansour et al. (2019), high-pressure $\mathrm{CO}_{2}$ dissolves in the oil, swells it, and reduces its viscosity, increasing dramatically the gas solubility and the drive energy available to reservoir production. For this particular reason, and considering environmental issues, re-injection of $\mathrm{CO}_{2}$ has become an important strategy for enhanced oil recovery. It is therefore safe to say that PVT correlations that do not account for higher carbon dioxide compositions tend to estimate over-predicted $\mu_{o}$ data and underpredicted $R_{s}$ values.
To the best of knowledge, most of the published contributions encompassing the presence of high $\mathrm{CO}_{2}$ contents in oil mixtures refer to equation of state modeling (Elias et al., 2014), assessment of $\mathrm{CO}_{2}$-oil miscibility pressure (Shokrollahi et al., 2015), and development of specific $\mathrm{CO}_{2}$-dead oil viscosity and solubility models (e.g. Welker \& Dunlop, 1963; Simon \& Graue, 1965; Barclay \& Mishra, 2016). In this context, future studies should focus on considering the $\mathrm{CO}_{2}$ composition either as an independent variable in empirical correlations or as a validity range within which such models could be well-represented. Nevertheless, compositional modeling and simulation would be preferable since the accuracy of PVT correlations depend highly on the specific geographical regions from where the oil mixtures are retrieved, which may render them fairly laborious work due to the necessity of acquiring an extensive amount of field data.

\section{CONCLUSIONS}

Bubble point pressure, solution gas-oil ratio, and oil formation volume factor are interpreted as being the most relevant parameters for reservoir engineering and field development. Such PVT data may be acquired either from laboratory analysis or, in case of its absence, through empirical correlations.

Numerous models have been proposed for different oil types and reserves around the world. However, there is a lack of studies regarding the Brazilian pre-salt region. Specifically, since it has reshaped the Brazil's economy and has the potential of making it one of the world's biggest holders of oil reserves. Hence, we compared twenty empirical correlations for the determination of the under-saturated oil viscosity, solution gas-oil ratio, and oil formation volume factor of oil samples from the Campos Basin reserves in the Brazilian pre-salt region originally evaluated by Elias \& Trevisan (2016). The results obtained by the authors were tested against each correlation to determine the model with the best prediction of performance.

The qualitative comparison was performed by plotting the data in regression crossplots, whereas the quantitative analysis was carried out through the calculation of the Average Absolute Relative 
Error (AARE), Root Mean Square Error (RMSE), and Standard Error of Estimate (SEE). From our results, and with regard to the Campos Basin fluids, AlShammasi's (2001) correlation proved to be the best estimation model for solution gas-oil ratio, whereas Al-Marhoun (1985) and Beal's (1946) correlations were deemed the most accurate for the prediction of oil formation volume factor and under-saturated oil viscosity, respectively.

Although the analysis of the present work was carried out in terms of a relatively limited range of data, it is believed that the purpose of providing a statistical comparison and defining the known correlations for predicting PVT properties of presalt fluids from the Campos Basin area could be appropriately achieved. Nevertheless, future works should aim at gathering a more substantial amount of laboratory data to develop a specific model for such fluids.

\section{ACKNOWLEDGMENTS}

This study was financed in part by the Coordenação de Aperfeiçoamento de Pessoal de Nível Superior Brasil (CAPES) - Finance Code 001.

\section{SYMBOLS}

\begin{tabular}{ll}
$B_{o}$ & Oil formation-volume-factor \\
$B_{o b}$ & Bubble-point oil formation-volume-factor \\
$C_{o}$ & Under-saturated oil compressibility \\
$n$ & Number of experimental data points \\
$P$ & Pressure \\
$P_{b}$ & Bubble-point pressure \\
$P_{\text {sep }}$ & Separator pressure \\
$R_{s}$ & Solution gas-oil ratio \\
$R_{s b}$ & Bubble-point gas-oil ratio \\
$S C$ & Standard Conditions \\
$T$ & Temperature \\
$T_{s e p}$ & Separator temperature \\
$\left(V_{g}\right)^{S C}$ & Volume of gas produced under standard \\
$\left(V_{o}\right)^{S C}$ & conditions \\
\hline
\end{tabular}

$\begin{array}{ll}\left(V_{R}\right)_{T, P} & \begin{array}{l}\text { Volume of oil and dissolved gas under } \\ \text { reservoir conditions }\end{array} \\ X_{\text {calc }} & \text { Calculated value } \\ X_{\text {exp }} & \text { Experimental result }\end{array}$

\section{Greek symbols}

$\begin{array}{ll}v_{\mathrm{API}} & \text { Oil API gravity } \\ \gamma_{\mathrm{g}} & \text { Gas gravity } \\ \gamma_{\mathrm{o}} & \text { Oil gravity } \\ \mu_{\mathrm{o}} & \text { Under-saturated oil viscosity } \\ \mu_{\mathrm{ob}} & \text { Bubble-point oil viscosity } \\ \mu_{\mathrm{od}} & \text { Dead oil viscosity }\end{array}$

\section{ABBREVIATIONS}

AARE

API

CAPES

PVT

RMSE

SEE
Average Absolute Relative Error

American Petroleum Institute

Coordenação de Aperfeiçoamento de Pessoal de Nível Superior

Pressure-Volume-Temperature

Root Mean Square Error

Standard Error of Estimate

\section{REFERENCES}

Abedini, R.; Abedini, A.; Yakhfrouzan, N. E. A new correlation for prediction of undersaturated crude oil viscosity. Petroleum \& Coal, v.52, p. 5055, 2010.

Abdul-Majeed, G.H.; Salman, N.H. An empirical correlation for oil FVF prediction. Journal of Canadian Petroleum Technology, v.27, p. 118-122, 1988. https://doi.org/10.2118/88-06-10

Abdul-Majeed, G.H.; Kattan, R.R.; Salman, N.H. New Correlation for Estimating the Viscosity of Undersaturated Crude Oils. Journal of Canadian Petroleum Technology, v.29, p. 80-85, 1990. https://doi.org/10.2118/90-03-10 
Ahmadi, A.; Abdideh, M.; Amiri, F. Thermodynamic analysis PVT equation of state definition and gas injection review along with case study in three wells of Iranian oil field. Energy Sources, Part A: Recovery, Utilization, and Environmental Effects, p.1-19, 2019. https://doi.org/10.1080/15567036.2019.1610525

Ahmed, T. Reservoir engineering handbook. Fourth ed. Oxford: Gulf Professional Publishing, 2010. 1524p.

Al-Marhoun, M.A. Black oil property correlations - State of the art. In: SPE Middle East Oil \& Gas Show and Conference, MEOS 2015, Manama, p. 1-12, 2015. https://doi.org/10.2118/172833-MS

Al-Marhoun, M.A. PVT correlations for Middle East crude oils. In: SPE Middle East Oil Technical Conference \& Exhibition, MEOTCE 1985, Manama, 1985.

Al-Shammasi, A.A. A Review of Bubble Point Pressure and Oil Formation Volume Factor Correlations. SPE Reservoir Evaluation \& Engineering, v.4, p. 146-160, 2001.

https://doi.org/10.2118/71302-PA

Almehaideb, R.A. Improved PVT correlations for UAE crude oils. In: Middle East Oil Show and Conference, MEOS 1997, Manama, p. 109-120, 1997. https://doi.org/10.2118/37691-MS

Alqahtani, N.B.; AlQuraishi, A.A.; Al-Baadani, W. New correlations for prediction of saturated and undersaturated oil viscosity of Arabian oil fields. Journal of Petroleum Exploration and Production Technology, v.8, p. 205-216, 2018.

https://doi.org/10.1007/s13202-017-0332-4

Arabloo, M.; Amooiea, M.A.; Hemmati, S.A.; Ghazanfari, M.H.; Mohammadi, A.H. Application of constrained multi-variable search methods for prediction of PVT properties of crude oil systems. Fluid Phase Equilibria, v.363, p. 121-130, 2015. https://doi.org/10.1016/i.fluid.2013.11.012

Arinelli, L.O.; de Medeiros, J.L.; Araújo,O.Q. Performance Analysis and Comparison of Membrane Permeation Versus Supersonic Separators for $\mathrm{CO}_{2}$ Removal From a Plausible Natural Gas of Libra Field, Brazil. In: Offshore Technology Conference, OTC Brasil 2015, Rio de Janeiro, p. 1-12, 2015. https://doi.org/10.4043/26164$\underline{\mathrm{MS}}$
Asadisaghandi, J.; Tahmasebi, P. Comparative evaluation of back-propagation neural network learning algorithms and empirical correlations for prediction of oil PVT properties in Iran oilfields. Journal of Petroleum Science and Engineering, v.78, p. 464-475, 2011.

https://doi.org/10.1016/i.petrol.2011.06.024

Barclay, T.H.; Mishra, S. New correlations for $\mathrm{CO}_{2}$-Oil solubility and viscosity reduction for light oils. Journal of Petroleum Exploration and Production Technology, v.6, p. 815-823, 2016. https://doi.org/10.1007/s13202-016-0233-y

Beal, C. The viscosity of air, water, natural gas, crude oil and its associated gases at oil field temperature and pressures. Transactions, v.165, p. 94-115, 1946. https://doi.org/10.2118/946094-G

Beltrão, R.L.C.; Sombra, C.L.; Lage, A.C.V.M.; Netto, J.R.F.; Henriques, C.C.D. Challenges and new technologies for the development of the pre-salt cluster, Santos Basin, Brazil. In: Offshore Technology Conference, OTC 2009, Houston, p. 111, 2009. https://doi.org/10.4043/OTC-19880-MS

Bergman, D.F.; Sutton, R.P. Undersaturated Oil Viscosity Correlation for Adverse Conditions. SPE Annual Technical Conference and Exhibition, ATCE 2006, San Antonio, p. 1-20, 2006.

Caixerio, E. Correlation of reservoir properties, Miranga field. M.Sc. Report, Stanford University, 1976.

Danesh, A. PVT and phase behaviour of petroleum reservoir fluids. Vol. 47, First ed. Amsterdam: Elsevier Science, 1998. 400p.

De Ghetto, G.; Paone, F.; Villa, M. Reliability Analysis on PVT Correlations. In: SPE European Petroleum Conference, EPC94, London, p. 375-393, 1994. https://doi.org/10.2118/28904-MS

Dindoruk, B.; Christman, P.G. PVT Properties and Viscosity Correlations for Gulf of Mexico Oils. In: SPE Annual Technical Conference and Exhibition, ATCE 2004, New Orleans, p. 427-437, 2004. https://doi.org/10.2118/89030-PA

Dokla, M.E.; Osman, M.E. Correlation of PVT properties for UAE crudes. SPE Formation Evaluation, v.7, p. 41-46, 1992.

https://doi.org/10.2118/20989-PA 
El-Banbi, A.H.; Fattah, K.A.; Sayyouh, M.H. New modified black-oil PVT correlations for Gas condensate and volatile oil fluids. In: SPE Annual Technical Conference and Exhibition, ATCE 2006, San Antonio, p. 1-6, 2006.

https://doi.org/10.2118/102240-MS

Elam, F.M. Prediction of bubble point pressure and formation volume factors from field data. M.Sc. Thesis, Texas A\&M University, 1957.

Elias, A.; Mello, S.F.; Schiozer, D.J.; Trevisan, O.V. PVT analysis process of pre-salt similar oil associated with compositional simulation. In: Rio Oil \& Gas Expo and Conference 2014, p.1-9, 2014.

Elias, A.; Trevisan, O.V. An experimental investigation on phase behavior of a light oil and $\mathrm{CO}_{2}$. Journal of Petroleum Science and Engineering, v.145, p. 22-33, 2016. https://doi.org/10.1016/i.petrol.2016.03.006

Elsharkawy, A.M.; Alikhan, A.A. Models for predicting the viscosity of Middle East crude oils. Fuel, v.78, p. 891-903, 1999.

https://doi.org/10.1016/S0016-2361(99)00019-8

Elsharkawy, A.M.; Alikhan, A.A. Correlations for predicting solution gas-oil ratio, oil formation volume factor and undersaturated oil compressibility. Journal of Petroleum Science and Engineering, v.17, p. 291-302, 1997. https://doi.org/10.1016/S0920-4105(96)00075-7

Elsharkawy, A.M.; Elgibaly, A.A.; Alikhan, A.A. Assessment of the PVT correlations for predicting the properties of Kuwaiti crude oils. Journal of Petroleum Science and Engineering, v.13, p. 219232, $1995 . \quad$ https://doi.org/10.1016/09204105(95)00012-7

Farshad, F.F.; LeBlance, J.L.; Garbeer, J.O.; Osorio, J.G. Empirical PVT Correlations for Colombian Crudes. In: SPE Latin America/Caribbean Petroleum Engineering Conference, LACPEC 1992, Port of Spain, p. 311-320, 1992.

Gharbi, R.; Elsharkawy, A.M. Predicting the Bubble-Point Pressure and Formation-VolumeFactor of Worldwide Crude Oil Systems. Petroleum Science and Technology, v.21, p. 53-79, 2003. https://doi.org/10.1081/LFT-120016921

Glas $\varnothing$, O. Generalized pressure-volumetemperature correlations. Journal of Petroleum Technology, v.32, p. 785-795, 1980.

https://doi.org/10.2118/8016-PA
Hasan, M.; Lestari; Inawati. PVT Correlations for Indonesian Crude Oils. In: 22nd Annual Convention of the Indonesian Petroleum Association, 22nd Annual Convention Proceedings, p. 237-254, 1993.

Hemmati, M.N.; Kharrat, R. A correlation approach for prediction of crude oil PVT properties. In: SPE Middle East Oil and Gas Show and Conference, MEOS 2007, Manama, 2007. https://doi.org/10.2118/104543-MS

Hemmati-Sarapardeh, A.; Khishvand, M.; Naseri, A.; Mohammadi, A.H. Toward reservoir oil viscosity correlation. Chemical Engineering Science, v.90, p. 53-68, 2013. https://doi.org/10.1016/i.ces.2012.12.009

Hossain, M.S.; Sarica, C.; Zhang, H.-Q. Assessment and development of heavy-oil viscosity correlations. In: SPE/PS-CIM/CHOA International Thermal Operations and Heavy Oil Symposium, ITOHOS 2005, Calgary, p. 1-9, 2005. https://doi.org/10.2118/97907-MS

Ikiensikimama, S.S.; Ajienka, J.A. Impact of PVT correlations development on hydrocarbon accounting: The case of the Niger Delta. Journal of Petroleum Science and Engineering, v.81, p. 80-85, 2012. https://doi.org/10.1016/i.petrol.2011.12.017

Isehunwa, O.S.; Olamigoke, O.; Makinde, A.A. A Correlation to Predict the Viscosity of Light Crude Oils. In: SPE Nigeria Annual International Conference and Exhibition, NAICE2006, Abuja, p. 17, 2006. https://doi.org/10.2118/105983-MS

Jarrahian, A.; Moghadasi, J.; Heidaryan, E. Empirical estimating of black oils bubble point (saturation) pressure. Journal of Petroleum Science and Engineering, v.126, p. 69-77, 2015. https://doi.org/10.1016/j.petrol.2014.12.004

Johann, P.; Monteiro, R.C. Geophysical Reservoir Characterization and Monitoring at Brazilian Pre-Salt Oil Fields. In: Offshore Technology Conference, 2016, OTC 2016, Houston, p. 1-27, 2016. https://doi.org/10.4043/27246-MS

Karimnezhad, M.; Heidarian, M.; Kamari, M.; Jalalifar, H. A new empirical correlation for estimating bubble point oil formation volume factor. Journal of Natural Gas Science and Engineering, v.18, p. 329-335, 2014. https://doi.org/10.1016/i.jngse.2014.03.010 
Kartoatmodjo, T.; Schmidt, Z. Large data bank improves crude oil physical property correlations. Oil \& Gas Journal, p. 51-55, 1994.

Kartoatmodjo, T.; Schmidt, Z. New Correlations For Crude Oil Physical Properties. SPE paper 23556, 1991.

Katz, D.L. Prediction of the Shrinkage of Crude Oils. Drilling and Production Practice. p. 137-147, 1942.

Khamis, M.A.; Fattah, K.A. Estimating oil-gas ratio for volatile oil and gas condensate reservoirs: artificial neural network, support vector machines and functional network approach. Journal of Petroleum Exploration and Production Technology, v.9, p. 573-582, 2019. https://doi.org/10.1007/s13202-018-0501-0

Khan, S.A.; Al-Marhoun, M.A.; Duffuaa, S.O.; Abu-Khamsin, S.A. Viscosity Correlations for Saudi Arabian Crude Oils. In: SPE Middle East Oil Show, MEOS 1987, Manama, p. 251-258, 1987. https://doi.org/10.2118/15720-MS

Knopp, C.R.; Ramsey, L.A. Correlation of oil formation volume factor and solution gas-oil ratio. Journal of Petroleum Technology, v.12, p. 27-29, 1960. https://doi.org/10.2118/1433-G

Kouzel, B. How pressure affects liquid viscosity. Hydrocarbon Processing \& Petroleum Refiner, v.44, p. 120, 1965.

Kutas, D.T. A Study of the Applicability of Bourgoyne \& Young ROP Model and Fitting Reliability through Regression. In: International Petroleum Conference, IPTC 2015, Doha, p. 1-14, 2015. https://doi.org/10.2523/IPTC-18521-MS

Labedi, R. Improved correlations for predicting the viscosity of light crudes. Journal of Petroleum Science and Engineering, v.8, p.221-234, 1992. https://doi.org/10.1016/0920-4105(92)90035-Y

Labedi, R. Use of production data to estimate volume factor density and compressibility of reservoir fluids. Journal of Petroleum Science and Engineering, v.4, p. 357-390, 1990.

https://doi.org/10.1016/0920-4105(90)90034-Z

Lasater, J.A. Bubble point pressure correlation. Journal of Petroleum Technology, v.10, p. 65-67, 1958. https://doi.org/10.2118/957-G
Levitan, L.L.; Murtha, M. New Correlations Estimate Pb, FVF. Oil \& Gas Journal, v.97, p. 70, 1999. https://doi.org/10.1016/S0026-0576(99)80583-2

Macary, S.; El-Batanoney, M. Derivation of PVT correlations for the Gulf of Suez crude oils. Journal of the Japan Petroleum Institute, v.36, p. 472-478, 1993. https://doi.org/10.1627/ipi1958.36.472

Magalhães, A.S.; Domingues, E.P. Blessing or curse: Impacts of the Brazilian Pre-Salt oil exploration. EconomiA, v.15, p. 343-362, 2014. https://doi.org/10.1016/j.pet/m.2015.12.001

Mahdiani, M.R.; Kooti, G. The most accurate heuristic-based algorithms for estimating the oil formation volume factor. Petroleum, v.2, p. 40-48, 2016. https://doi.org/10.1016/i.pet/m.2015.12.001

Management Centre Europe. Oil \& Gas Industry. Available at: https://mce.eu/oil-gas/. Accessed on: 29 October 2018.

Mansour, E.M.; Al-Sabagh, A.M.; Desouky, S.M.; Zawawy, F.M.; Ramzi, M. A laboratory investigation of carbon dioxide-enhanced oil recovery by focusing on $\mathrm{CO}_{2}$-oil physical properties. Egyptian Journal of Petroleum, v.28, p. 21-26, 2019. https://doi.org/10.1016/i.ejpe.2018.10.004

Mansour, E.M.; Farag, A.B.; El-Dars, F.S.; Desouky, S.M.; Batanoni, M.H.; Mahmoud, M.R.M. Predicting PVT properties of Egyptian crude oils by a modified Soave-Redlich-Kowng equation of state. Egyptian Journal of Petroleum, v.22, p. 137148, 2013. https://doi.org/10.1016/i.ejpe.2012.09.005

Mazandarani, M.T.; Asghari, S.M. Correlations for predicting solution gas-oil ratio, bubble point pressure, and oil formation volume factor at bubble Point of Iran crude oils. In: 6th European Congress of Chemical Engineering, ECCE-6, Copenhagen, p. 1-8, 2007.

Nnabuo, N.N.; Okafor, I.S.; Ubani, C.E. Interpretation of Laboratory PVT Analysis Result (A Case Study of a Niger Delta Field). In: SPE Nigeria Annual International Conference and Exhibition, NAICE2014, Lagos, p. 1-10, 2014. https://doi.org/10.2118/172412-MS

Obomanu, D.A.; Okpobiri, G.A. Correlating the PVT properties of Nigerian crudes. Journal of Energy Resources Technology, v.109, p. 214-217, 1987. https://doi.org/10.1115/1.3231349 
Olatunji, S.O.; Selamat, A.; Raheem, A.A.A. Predicting correlations properties of crude oil systems using type-2 fuzzy logic systems. Expert Systems with Applications, v.38, p. 10911-10922, 2011. https://doi.org/10.1016/i.eswa.2011.02.132

Omar, M.I.; Todd, A.C. Development of new modified black oil correlations for Malaysian crudes. In: SPE Asia Pacific Oil and Gas Conference, APOGCE 1993, Singapore, p. 211-219, 1993. https://doi.org/10.2118/25338-MS

Ostermann, R.D.; Owolabi, O.O. Correlations for the reservoir fluid properties of Alaskan crudes. In: SPE California Regional Meeting, CRM 1983, Ventura, p. 357-366, 1983.

https://doi.org/10.2118/11703-MS

Pedersen, K.S.; Christensen, P.L.; Shaikh, J.A. Phase behavior of petroleum reservoir fluids. Second ed. New York: CRC Press, 2015. https://doi.org/10.1201/b17887

Petrosky, G.E.; Farshad, F.F. Viscosity correlations for Gulf of Mexico crude oils. In: SPE Production Operations Symposium, SPEPOS 1995, Oklahoma City, p. 249-258, 1995.

https://doi.org/10.2118/29468-MS

Petrosky, G.E.; Farshad, F.F. Pressure volume temperature correlations for Gulf of Mexico crude oils. SPE Reservoir Evaluation \& Engineering, v.1, p. 416-420, 1993. https://doi.org/10.2118/51395-PA

Potsch, K.; Toplack, P.; Gumpenberger, T. A Review and Extension of Existing Consistency Testes for PVT Data from a Laboratory. SPE Reservoir Evaluation \& Engineering, v.20, p. 1-16, 2017. https://doi.org/10.2118/183640-PA

Pré-Sal Petróleo S.A. Campos Basin - Where It
All $\quad$ Starts. Available at: https://www.presalpetroleo.gov.br/ppsa_eng/thepre-salt/campos-basin. Accessed on: 05 July 2019.

Rafiee-Taghanaki, S.; Arabloo, M.; Chamkalani, A.; Amani, M.; Zargari, M.H.; Adelzadeh, M.R. Implementation of SVM framework to estimate PVT properties of reservoir oil. Fluid Phase Equilibria, v.346, p. 25-32, 2013. https://doi.org/10.1016/i.fluid.2013.02.012
Rasouli, H.; Rashidi, F.; Ebrahimian, A. Estimating the Bubble Point Pressure and Formation Volume Factor of Oil Using Artificial Neural Networks. Chemical Engineering \& Technology, v.31, p. 493-500, 2008. https://doi.org/10.1002/ceat.200700434

Salehinia, S.; Salehinia, Y.; Alimadadi, F.; Sadati, S.H. Forecasting density, oil formation volume factor and bubble point pressure of crude oil systems based on nonlinear system identification approach. Journal of Petroleum Science and Engineering, v.147, p. 47-55, 2016.

https://doi.org/10.1016/i.petrol.2016.05.008

Shokrollahi, A.; Tatar, A.; Safari, H. On accurate determination of PVT properties in crude oil systems: Committee machine intelligent system modelling approach. Journal of the Taiwan Institute of Chemical Engineers, v. 55, p. 17-26, 2015. https://doi.org/10.1016/i.jtice.2015.04.009

Simon, R.; Graue, D.J. Generalized Correlations for Predicting Solubility, Swelling and Viscosity Behavior of $\mathrm{CO}_{2}$-Crude Oil Systems. Journal of Petroleum Technology, v.17, p. 102-106, 1965. https://doi.org/10.2118/917-PA

Standing, M.B. A Pressure Volume Temperature Correlation for Mixture of California Oils and Gases. Drilling and Production Practice, p. 275-287, 1947.

Sulaimon, A.A.; Ramli, N.; Adeyemi, B.J. New Correlation for Oil Formation Volume Factor. In: SPE Nigerian Annual International Conference and Exhibition, NAICE2014, Lagos, p. 1-6, 2014. https://doi.org/10.2118/172396-MS

Taghizadeh, M.; Eftekhari, M. Improved correlations for prediction of viscosity of Iranian crude oils. Chinese Journal of Chemical Engineering, v.22, p. 346-354, 2014.

https://doi.org/10.1016/S1004-9541(14)60017-3

Talebi, R.; Ghiasi, M.M.; Talebi, H.; Mohammadyian, M.; Zendehboudi, S.; Arabloo, M.; Bahadori, A. Application of soft computing approaches for modeling saturation pressure of reservoir oils. Journal of Natural Gas Science and Engineering, v.20, p. 8-15, 2014.

https://doi.org/10.1016/i.jngse.2014.04.023 
Torabi, F.; Jamaloei, B.Y.; Zunti, C.J.; Markwart, C. C. The Prediction of Viscosity, Formation Volume Factor, and Bubble Point Pressure of Heavy Oil Using Statistical Analysis, Artificial Neural Networks, and Three-dimensional Modeling: A Comparative Evaluation. Energy Sources, v.36, p. 874-889, 2014.

https://doi.org/10.1080/15567036.2010.547926

Vazquez, M.E.; Beggs, H.D. Correlations for fluid physical property prediction. Journal of Petroleum Technology, v.32, p. 968-970, 1980.

https://doi.org/10.2118/6719-PA

Welker, J.; Dunlop, D. Physical properties of carbonated oils. Journal of Petroleum Technology, v.5, p. 873-875, 1963. https://doi.org/10.2118/567PA

\section{APPENDIX A}

\section{Solution gas-oil ratio correlations}

\section{Standing (1947)}

$R_{s}=\gamma_{g}\left[\left(\frac{P}{18.2}+1.4\right) 10^{0.0125 \gamma_{A P l}-0.00091(T-460)}\right]^{1.2048}$

where $\gamma_{\mathrm{g}}=$ gas gravity, $\mathrm{P}=$ pressure $(\mathrm{psi}), \gamma_{\mathrm{API}}=$ oil API (American Petroleum Institute) gravity, $T=$ temperature $\left({ }^{\circ} \mathrm{F}\right)$.

\section{Glas $\varnothing(1980)$}

$R_{s}=\gamma_{g}\left\{\left[\frac{\gamma_{A P I}^{0.989}}{(T-460)^{0.172}}\right] 10^{2.8869-\left[14.1811-3.3093 \log _{10}(P)\right]^{0.5}}\right\}^{1.2255}$

where $\gamma_{\mathrm{g}}=$ gas gravity, $\mathrm{P}=$ pressure $(\mathrm{psi}), \gamma_{\mathrm{API}}=$ oil API gravity, $T=$ temperature $\left({ }^{\circ} \mathrm{R}\right)$.

\section{Vazquez and Beggs (1980)}

$R_{s}=C_{1} \gamma_{g}\left[1+5.912 \cdot 10^{-5} \gamma_{A P I}\left(T_{s e p}-460\right) \log _{10}\left(\frac{P_{s e p}}{114.7}\right)\right] \times$

$\times P^{C_{2}} \exp \left[C_{3}\left(\frac{\gamma_{A P I}}{T}\right)\right]$

where $C_{1}=0.0362, C_{2}=1.0937, C_{3}=25.724, \gamma_{\mathrm{g}}=$ gas gravity, $\mathrm{P}_{\text {sep }}=$ separator pressure (psia), $\mathrm{P}=$ pressure (psia), $\quad V_{\text {API }}=$ oil API gravity, $\mathrm{T}=$ temperature $\left({ }^{\circ} \mathrm{R}\right), \mathrm{T}_{\text {sep }}=$ separator temperature $\left({ }^{\circ} \mathrm{R}\right)$.

\section{Ostermann and Owolabi (1983)}

$55+0.8643\left[\left(\frac{R_{s}}{\gamma_{g}}\right)^{1.255} \frac{T^{0.172}}{\gamma_{A P I}^{0.178}}\right]-P=0$

where $\gamma_{\mathrm{g}}=$ gas gravity, $\mathrm{P}=$ pressure (psi), $v_{\mathrm{API}}=$ oil API gravity, $T=$ temperature $\left({ }^{\circ} \mathrm{R}\right)$.

\section{Al-Marhoun (1985)}

$R_{s}=\left(185.843208 \gamma_{g}^{1.87784} \gamma_{o}^{-3.1437} T^{-1.32657} P\right)^{1.39844}$

where $\nu_{\mathrm{g}}=$ gas gravity, $\mathrm{P}=$ pressure $(\mathrm{psi}), \gamma_{\mathrm{o}}=$ oil gravity, $\mathrm{T}=$ temperature $\left({ }^{\circ} \mathrm{R}\right)$.

\section{Obomanu and Okpobiri (1987)}

$R_{s}=\frac{0.03008 P^{0.927} \gamma_{g}^{2.15} \gamma_{A P I}^{1.27}}{10^{0.811} T^{0.497}}$

where $\gamma_{\mathrm{g}}=$ gas gravity, $\mathrm{P}=$ pressure (psi), $\gamma_{\mathrm{API}}=$ oil API gravity, $\mathrm{T}=$ temperature $\left({ }^{\circ} \mathrm{F}\right)$.

Farshad et al. (1992)

$$
\begin{aligned}
& 10^{0.3058+1.9013^{*} \log (X)-0.26\left[\log (X)^{2}\right]}-P=0 \\
& X=\gamma_{g}^{-1.378} R_{s}^{1.053} 10^{0.00069(T-460)-0.0208 \gamma_{A P I}}
\end{aligned}
$$

where $\gamma_{\mathrm{g}}=$ gas gravity, $\mathrm{P}=$ pressure (psi), $\gamma_{\mathrm{API}}=$ oil API gravity, $T=$ temperature $\left({ }^{\circ} R\right)$.

Hasan et al. (1993)

$$
R_{s}=\left[(0.0546 P-2.2) \frac{\gamma_{g}}{10^{0.00091 T-0.0125 \gamma_{A P I}}}\right]^{1.205}
$$

where $\gamma_{\mathrm{g}}=$ gas gravity, $\mathrm{P}=$ pressure (psi), $\gamma_{\mathrm{API}}=$ oil API gravity, $T=$ temperature $\left({ }^{\circ} \mathrm{F}\right)$.

\section{Macary and El-Batanoney (1993)}

$R_{s}=\left[0.0049 \frac{P}{\exp \left(0.00077 T-0.0097 \gamma_{A P I}-0.4003 \gamma_{g}\right)}+4.7927\right]^{1.9606}$

where $\gamma_{\mathrm{g}}=$ gas gravity, $\mathrm{P}=$ pressure $(\mathrm{psi}), \gamma_{\mathrm{API}}=$ oil API gravity, $\mathrm{T}=$ temperature $\left({ }^{\circ} \mathrm{F}\right)$.

\section{Petrosky and Farshad (1993)}

$R_{s}=\left[\left(\frac{P}{112.727}+12.34\right) \gamma_{g}^{0.8439} 10^{7.916 \cdot 10^{-4} \gamma_{A P P}^{1.541}-4.561 \cdot 10^{-5}(T-460)^{1.3911}}\right]^{1.73184}$ 
where $\gamma_{\mathrm{g}}=$ gas gravity, $\mathrm{P}=$ pressure $(\mathrm{psi}), \gamma_{\mathrm{API}}=$ oil API gravity, $T=$ temperature $\left({ }^{\circ} \mathrm{R}\right)$.

\section{Kartoatmodjo and Schmidt (1994)}

$R_{s}=P^{1.001402} 0.05958 \gamma_{g}^{0.7972} 10 \frac{13.1405 \gamma_{A P L}}{T}$

where $\nu_{\mathrm{g}}=$ gas gravity, $\mathrm{P}=$ pressure $(\mathrm{psi}), \gamma_{\mathrm{API}}=$ oil API gravity, $T=$ temperature $\left({ }^{\circ} \mathrm{R}\right)$.

\section{Elsharkawy and Alikhan (1997)}

$R_{s}=\gamma_{g} P^{1.18026} 10^{-1.2179+0.4636}\left(\frac{\gamma_{A P I}}{T}\right)$

where $\gamma_{\mathrm{g}}=$ gas gravity, $\mathrm{P}=$ pressure $(\mathrm{psi}), \nu_{\mathrm{API}}=$ oil API gravity, $T=$ temperature $\left({ }^{\circ} \mathrm{R}\right)$.

\section{Levitan and Murtha (1999)}

$R_{s}=\gamma_{g}\left[805.887 P \gamma_{o}^{-1.5} T^{-1.5}\right]^{1.1765}$

where $\gamma_{\mathrm{g}}=$ gas gravity, $\mathrm{P}=$ pressure $(\mathrm{psi}), \gamma_{\mathrm{o}}=$ oil gravity, $T=$ temperature $\left({ }^{\circ} R\right)$.

\section{Al-Shammasi (2001)}

$R_{s}=\left[\exp \left(1.841408 \gamma_{g} \gamma_{o}\right) P \gamma_{o}^{-5.527215} \gamma_{g}^{-0.783716} T^{-0.783716}\right]^{1.276}$ where $\gamma_{\mathrm{g}}=$ gas gravity, $\mathrm{P}=$ pressure $(\mathrm{psi}), \gamma_{\mathrm{o}}=$ oil gravity, $\mathrm{T}=$ temperature $\left({ }^{\circ} \mathrm{R}\right)$.

\section{Dindoruk and Christman (2004)}

$$
\begin{aligned}
& R_{s}=\left[\left(\frac{P}{3.35975497}+28.10133245\right) \gamma_{g}^{1.57905016} 10^{X}\right]^{0.92813144} \\
& X=\frac{4.86996 \cdot 10^{-6} \gamma_{A P I}^{5.730982539}+9.9251 \cdot 10^{-3}(T-460)^{1.776179364}}{\left(44.2500268+\frac{2 \gamma_{A P I}^{2.702889206}}{P^{0.744335673}}\right)^{2}}
\end{aligned}
$$

where $\gamma_{\mathrm{g}}=$ gas gravity, $\mathrm{P}=$ pressure $(\mathrm{psi}), \gamma_{\mathrm{API}}=$ oil API gravity, $T=$ temperature $\left({ }^{\circ} \mathrm{R}\right)$.

\section{$\underline{\text { Hemmati and Kharrat (2007) }}$}

$$
R_{s}=\left[0.1769 \gamma_{g}^{1.0674} \gamma_{o}^{-5.0956} T^{-0.1394} P\right]^{1.0857}
$$

where $\gamma_{\mathrm{g}}=$ gas gravity, $\mathrm{P}=$ pressure (psi), $\nu_{\mathrm{o}}=$ oil gravity, $\mathrm{T}=$ temperature $\left({ }^{\circ} \mathrm{F}\right)$.

\section{Mazandarani and Asghari (2007)}

$R_{s}=994.3718 \gamma_{g}^{2.113367} P^{1.4556} \gamma_{o}^{-5.48944} T^{-1.90488}$ where $\gamma_{\mathrm{g}}=$ gas gravity, $\mathrm{P}=$ pressure $(\mathrm{psi}), \gamma_{\mathrm{o}}=$ oil gravity, $\mathrm{T}=$ temperature $\left({ }^{\circ} \mathrm{R}\right)$.

Ikiensikimama and Ajienka (2012)

$R_{s}=\left[(0.059155 P+1.40573) 10^{0.0128746 \gamma_{A P I}-0.000913115 T}\right]^{1.23153}$ where $\mathrm{P}=$ pressure $(\mathrm{psi}), V_{\mathrm{API}}=$ oil API gravity, $\mathrm{T}=$ temperature $\left({ }^{\circ} \mathrm{F}\right)$.

Arabloo et al. (2015)

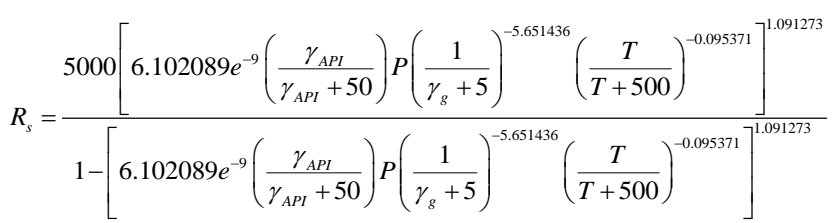
where $\gamma_{\mathrm{g}}=$ gas gravity, $\mathrm{P}=$ pressure $(\mathrm{psi}), v_{\mathrm{API}}=$ oil API gravity, $\mathrm{T}=$ temperature $\left({ }^{\circ} \mathrm{F}\right)$.

Jarrahian et al. (2015)

$R_{s}=\left[\frac{33.382 P \gamma_{g}^{0.448067}}{\gamma_{o}^{3.32023} \exp \left(\frac{-0.542446 \gamma_{g}}{\gamma_{o}}\right) T^{1.074756}}\right]^{1.21255}$

where $\gamma_{\mathrm{g}}=$ gas gravity, $\mathrm{P}=$ pressure $(\mathrm{psi}), \gamma_{\mathrm{API}}=$ oil API gravity, $T=$ temperature $\left({ }^{\circ} \mathrm{R}\right)$.

\section{APPENDIX B}

\section{Oil formation-volume-factor correlations}

Standing (1947)

$B_{o}=0.9759+0.00012\left[R_{s}\left(\frac{\gamma_{g}}{\gamma_{o}}\right)^{0.5}+1.25 T\right]^{1.2}$

where $\gamma_{\mathrm{g}}=$ gas gravity, $\gamma_{\mathrm{o}}=$ oil gravity, $\mathrm{T}=$ temperature $\left({ }^{\circ} \mathrm{F}\right), \mathrm{R}_{\mathrm{s}}=$ gas-oil ratio (scf/STB).

\section{$\underline{\text { Glasø (1980) }}$}

$B_{o}=1+10^{X}$

$X=-6.58511+2.91329 \log \left(R_{s}\left(\frac{\gamma_{g}}{\gamma_{o}}\right)^{0.526}+0.968 T\right)-$

$-0.27683 \log \left(R_{s}\left(\frac{\gamma_{g}}{\gamma_{o}}\right)^{0.526}+0.968 T\right)^{2}$ 
where $\gamma_{\mathrm{g}}=$ gas gravity, $\nu_{\mathrm{o}}=$ oil gravity, $\mathrm{T}=$ temperature $\left({ }^{\circ} \mathrm{F}\right), \mathrm{R}_{\mathrm{s}}=$ gas-oil ratio (scf/STB).

\section{Vazquez and Beggs (1980)}

$B_{o}=1+C_{1} R_{s}+(T-520)\left(\frac{\gamma_{A P I}}{\gamma_{g}\left[1+5.921 \cdot 10^{-5}\left(\gamma_{A P I}\right)\left(T_{s e p}-460\right) \log \left(\frac{P_{s e p}}{114.7}\right)\right]}\right)\left(C_{2}+C_{3} R_{s}\right)$

where $C_{1}=4.68 \times 10^{-4}, C_{2}=1.75 \times 10^{-5}, C_{3}=-1.81 \times 10^{-8}$, $V_{\mathrm{g}}=$ gas gravity, $\mathrm{P}_{\text {sep }}=$ separator pressure $(p s i a), V_{\text {API }}$ $=$ oil API gravity, $T=$ temperature $\left({ }^{\circ} \mathrm{R}\right), \mathrm{T}_{\text {sep }}=$ separator temperature $\left({ }^{\circ} R\right), R_{s}=$ gas-oil ratio (scf/STB).

\section{Al-Marhoun (1985)}

$B_{o}=0.497069+0.000862693 T+0.00182594 X+0.0000031809 X^{2}$ $X=R_{s}^{0.74239} \gamma_{g}^{0.323294} \gamma_{o}^{-1.20204}$

where $\gamma_{\mathrm{g}}=$ gas gravity, $\nu_{\mathrm{o}}=$ oil gravity, $\mathrm{T}=$ temperature $\left({ }^{\circ} \mathrm{R}\right), \mathrm{R}_{\mathrm{s}}$ = gas-oil ratio (scf/STB).

\section{Obomanu and Okpobiri (1987)}

$B_{o}=1.0232+0.0001065\left[R_{s}\left(\frac{\gamma_{g}}{\gamma_{o}}+1.8 T-460\right)\right]^{0.79}$

where $\gamma_{\mathrm{g}}=$ gas gravity, $\gamma_{\mathrm{o}}=$ oil gravity, $\mathrm{T}=$ temperature $(K), R_{S}=$ gas-oil ratio (scf/STB).

\section{Abdul-Majeed and Salman (1988)}

$B_{o}=0.563427+7.73 \cdot 10^{-4} T+4.8141 \cdot 10^{-5} X-6.8987 \cdot 10^{-10} X^{2}$

$X=R_{s}^{1.2} \gamma_{g}^{-0.147} \gamma_{o}^{-5.222}$

where $\gamma_{\mathrm{g}}=$ gas gravity, $\gamma_{\mathrm{o}}=$ oil gravity, $\mathrm{T}=$ temperature $\left({ }^{\circ} \mathrm{R}\right), \mathrm{R}_{\mathrm{s}}=$ gas-oil ratio (scf/STB).

\section{Labedi (1990)}

$B_{o}=0.9897+0.0001364\left[R_{s}\left(\frac{\gamma_{g}}{\gamma_{o}}\right)^{0.5}+1.25 T\right]^{1.175}$

where $\gamma_{\mathrm{g}}=$ gas gravity, $\gamma_{\mathrm{o}}=$ oil gravity, $\mathrm{T}=$ temperature $\left({ }^{\circ} \mathrm{F}\right), \mathrm{R}_{\mathrm{s}}=$ gas-oil ratio (scf/STB).

\section{Dokla and Osman (1992)}

$B_{o}=0.408345+1.56667 \cdot 10^{-3} T+1.39775 \cdot 10^{-3} X-380525 \cdot 10^{-6} X^{2}$ $X=R_{s}^{0.773572} \gamma_{g}^{0.40402} \gamma_{o}^{-0.882605}$ where $\gamma_{\mathrm{g}}=$ gas gravity, $\nu_{\mathrm{o}}=$ oil gravity, $\mathrm{T}=$ temperature $\left({ }^{\circ} R\right), R_{s}=$ gas-oil ratio (scf/STB).

Farshad et al. (1992)

$B_{o}=1+10^{-2.6541+0.557 \log (X)+0.333 \log (X)^{2}}$

$X=R_{s}^{0.5956} \gamma_{g}^{0.2369} \gamma_{o}^{-1.3282}+0.0976 T$

where $\gamma_{\mathrm{g}}=$ gas gravity, $\nu_{\mathrm{o}}=$ oil gravity, $\mathrm{T}=$ temperature $\left({ }^{\circ} \mathrm{F}\right), \mathrm{R}_{\mathrm{s}}=$ gas-oil ratio (scf/STB).

\section{Macary and El-Batanoney (1993)}

$B_{o}=(1.0031+0.0008 T) \cdot \exp \left(0.0004 R_{s}+0.0006 \frac{\gamma_{o}}{\gamma_{g}}\right)$

where $\gamma_{\mathrm{g}}=$ gas gravity, $\gamma_{\mathrm{o}}=$ oil gravity, $\mathrm{T}=$ temperature $\left({ }^{\circ} \mathrm{R}\right), \mathrm{R}_{\mathrm{s}}=$ gas-oil ratio (scf/STB).

Omar and Todd (1993)

$B_{o}=0.972+0.0001472\left(R_{s}\left(\frac{\gamma_{g}}{\gamma_{o}}\right)^{0.5}+1.125 T^{X}\right)$

$X=1.166+0.000762 \frac{\gamma_{o}}{\gamma_{g}}-0.0399 \gamma_{g}$

where $\gamma_{\mathrm{g}}=$ gas gravity, $\gamma_{\mathrm{o}}=$ oil gravity, $\mathrm{T}=$ temperature $\left({ }^{\circ} \mathrm{F}\right), \mathrm{R}_{\mathrm{s}}=$ gas-oil ratio (scf/STB).

\section{Petrosky and Farshad (1993)}

$B_{o}=1.0113+7.2046 \cdot 10^{-5}\left[R_{s}^{0.3738}\left(\frac{\gamma_{g}^{0.2914}}{\gamma_{o}^{0.6265}}\right)+0.24626 T^{0.5371}\right]^{3.0936}$

where $\gamma_{\mathrm{g}}=$ gas gravity, $\gamma_{\mathrm{o}}=$ oil gravity, $\mathrm{T}=$ temperature $\left({ }^{\circ} \mathrm{F}\right), \mathrm{R}_{\mathrm{s}}=$ gas-oil ratio (scf/STB).

\section{Kartoatmodjo and Schmidt (1994)}

$$
B_{o}=0.98496+0.0001\left(R_{s}^{0.755} \gamma_{g}^{0.25} \gamma_{o}^{-1.5}+0.45 T\right)
$$

where $\gamma_{\mathrm{g}}=$ gas gravity, $\gamma_{\mathrm{o}}=$ oil gravity, $\mathrm{T}=$ temperature $\left({ }^{\circ} \mathrm{F}\right), \mathrm{R}_{\mathrm{s}}=$ gas-oil ratio (scf/STB).

\section{Almehaideb (1997)}

$B_{o}=1.122+0.00000141 R_{s} \frac{T}{\gamma_{o}^{2}}$

where $\gamma_{\mathrm{o}}=$ oil gravity, $\mathrm{T}=$ temperature $\left({ }^{\circ} \mathrm{F}\right), \mathrm{R}_{\mathrm{s}}=$ gas-oil ratio (scf/STB). 


\section{Elsharkawy and Alikhan (1997)}

$B_{o}=1+4.0428 \cdot 10^{-4} R_{s}+6.3802 \cdot 10^{-4}(T-60)+7.8 \cdot 10^{-6}\left[\frac{R_{s}(T-60) \gamma_{g}}{\gamma_{o}}\right]$

where $\gamma_{\mathrm{g}}=$ gas gravity, $\gamma_{\mathrm{o}}=$ oil gravity, $\mathrm{T}=$ temperature $\left({ }^{\circ} \mathrm{F}\right), \mathrm{R}_{\mathrm{s}}=$ gas-oil ratio (scf/STB).

El-Banbi et al. (2006)

$B_{o}=47.23-8.833\left[R_{s}\left(\frac{\gamma_{g}}{\gamma_{o}}\right)^{0.5}+1.325 T\right]^{0.0092}-36.6$

where $\gamma_{\mathrm{g}}=$ gas gravity, $\gamma_{\mathrm{o}}=$ oil gravity, $\mathrm{T}=$ temperature $\left({ }^{\circ} \mathrm{F}\right), \mathrm{R}_{\mathrm{s}}=$ gas-oil ratio (scf/STB).

Karimnezhad et al. (2014)

$B_{o}=\left[1.166\left(R_{s} \frac{\gamma_{o}}{\gamma_{g}}\right)^{-0.03}+4.4 \cdot 10^{-6}\left(R_{s} T\right)^{0.894}\right]^{X}$

$X=T^{-0.044} \gamma_{o}^{-1.52} \gamma_{g}^{0.161}$

where $\gamma_{\mathrm{g}}=$ gas gravity, $\gamma_{\mathrm{o}}=$ oil gravity, $\mathrm{T}=$ temperature $\left({ }^{\circ} R\right), R_{s}=$ gas-oil ratio (scf/STB).

\section{Sulaimon (2014)}

$B_{o}=0.0000009 R_{s}\left(\frac{\gamma_{g}}{\gamma_{o}}+T\right)+1.0367$

where $\gamma_{\mathrm{g}}=$ gas gravity, $\gamma_{\mathrm{o}}=$ oil gravity, $\mathrm{T}=$ temperature $\left({ }^{\circ} \mathrm{F}\right), \mathrm{R}_{\mathrm{s}}=$ gas-oil ratio (scf/STB).

Torabi et al. (2014)

$B_{o}=0.733+0.000014 P+0.00842 \gamma_{A P I}+0.00053 R_{s}$ where $\mathrm{P}=$ pressure (psi), $V_{\mathrm{API}}=$ oil API gravity, $\mathrm{T}=$ temperature $\left({ }^{\circ} \mathrm{F}\right), \mathrm{R}_{\mathrm{s}}=$ gas-oil ratio (scf/STB).

Mahdiani and Kooti (2016)

$B_{o}=1.1292-0.67343 \frac{R_{s}}{\left(T \gamma_{g}\right)^{2}}+8.3272 \cdot 10^{-6} T^{2}+$

$+0.00053679 R_{s}-0.0019306 T$

where $\nu_{\mathrm{g}}=$ gas gravity, $\mathrm{T}=$ temperature $\left({ }^{\circ} \mathrm{F}\right), \mathrm{R}_{\mathrm{s}}=$ gas-oil ratio (scf/STB).

\section{APPENDIX C}

\section{Under-saturated oil viscosity correlations}

\section{Beal (1946)}

$\mu_{o}=\mu_{o b}+0.001\left(P-P_{b}\right)\left(0.024 \mu_{o b}^{1.6}+0.038 \mu_{o b}^{0.56}\right)$

where $\mu_{\mathrm{ob}}=$ bubble-point oil viscosity (cP), $\mathrm{P}=$ pressure (psi), $\mathrm{P}_{\mathrm{b}}=$ bubble-point pressure (psi).

\section{Kouzel (1965)}

$\mu_{o}=\mu_{o b} \exp \left[\left(5.50318 \cdot 10^{-5}+3.77163 \cdot 10^{-5} \mu_{o b}^{0.278}\right)\left(P-P_{b}\right)\right]$

where $\mu_{\mathrm{ob}}=$ bubble-point oil viscosity (cP), $\mathrm{P}=$ pressure (psi), $P_{b}=$ bubble-point pressure (psi).

Vazquez and Beggs (1980)

$\mu_{o}=\mu_{o b}\left(P / P_{b}\right)^{X}$

$X=2.6 P^{1.187} \exp \left[-8.95 \cdot 10^{-5} P-11.513\right]$

where $\mu_{\mathrm{ob}}=$ bubble-point oil viscosity (cP), $\mathrm{P}=$ pressure (psi), $\mathrm{P}_{\mathrm{b}}=$ bubble-point pressure (psi).

Khan et al. (1987)

$\mu_{o}=\mu_{o b} \cdot \exp \left[9.6 \cdot 10^{-5}\left(P-P_{b}\right)\right]$

where $\mu_{\mathrm{ob}}=$ bubble-point oil viscosity (cP), $\mathrm{P}=$ pressure (psi), $P_{b}=$ bubble-point pressure (psi).

Abdul-Majeed et al. (1990)

$\mu_{o}=\mu_{o b}+1000 \cdot 10^{X-5.2106+1.11 \log \left[6.894757\left(P-P_{b}\right)\right]}$

$X=1.9311-0.89941 \ln \left(R_{s}\right)-0.001194 \gamma_{A P I}^{2}+1$

$+0.0092545 \gamma_{A P I} \ln \left(R_{s}\right)$

where $\mu_{\mathrm{ob}}=$ bubble-point oil viscosity ( $\left.\mathrm{CP}\right), \mathrm{P}=$ pressure (psi), $P_{b}=$ bubble-point pressure (psi), $v_{\text {API }}$ $=$ oil API gravity, $R_{s}=$ gas-oil ratio (scf/STB).

\section{Kartoatmodjo and Schmidt (1991)}

$\mu_{o}=1.00081 \mu_{o b}+$

$+1.127 \cdot 10^{-3}\left(P-P_{b}\right)\left(-6.517 \cdot 10^{-3} \mu_{o b}^{1.8148}+0.038 \mu_{o b}^{1.59}\right)$ 
where $\mu_{\mathrm{ob}}=$ bubble-point oil viscosity (cP), $\mathrm{P}=$ pressure (psi), $\mathrm{P}_{\mathrm{b}}=$ bubble-point pressure (psi).

\section{Labedi (1992)}

$\mu_{o}=\mu_{o b}-\left[\frac{10^{-2.488} \mu_{o d}^{0.9036} P_{b}^{0.6151}}{10^{0.01976 \gamma_{A P I}}}\right]\left[1-\left(\frac{P}{P_{b}}\right)\right]$

$\mu_{o d}=\frac{10^{9.224}}{\gamma_{A P I}^{4.7013} T^{0.6739}}$

where $\mu_{\mathrm{ob}}=$ bubble-point oil viscosity (cP), $\mu_{\mathrm{od}}=$ dead oil viscosity $(c P), P=$ pressure $(p s i), P_{b}=$ bubble-point pressure (psi), $V_{\mathrm{API}}=$ oil API gravity, $\mathrm{T}=$ Temperature $\left({ }^{\circ} \mathrm{F}\right)$.

\section{De Ghetto et al. (1994)}

$\mu_{o}=\mu_{o b}-\left[\left(1-\frac{P}{P_{b}}\right)\left(\frac{10^{-3.8055} \mu_{o d}^{1.4131} P_{b}^{0.6957}}{10^{-0.00288 \gamma_{A P I}}}\right)\right]$

where $\mu_{\mathrm{ob}}=$ bubble-point oil viscosity (cP), $\mu_{\mathrm{od}}=$ dead oil viscosity $(\mathrm{cP}), \mathrm{P}=$ pressure $(\mathrm{psi}), \mathrm{P}_{\mathrm{b}}=$ bubble-point pressure (psi), $v_{\mathrm{API}}=$ oil API gravity.

\section{Petrosky and Farshad (1995)}

$\mu_{o}=\mu_{o b}+1.3449 \cdot 10^{-3}\left(P-P_{b}\right) \cdot 10^{X}$

$X=-1.0146+1.3322 \log \left(\mu_{o b}\right)-$

$-0.4876\left(\log \left(\mu_{o b}\right)\right)^{2}-1.15036\left(\log \left(\mu_{o b}\right)\right)^{3}$

where $\mu_{\mathrm{ob}}=$ bubble-point oil viscosity $(\mathrm{cP}), \mathrm{P}=$ pressure (psi), $\mathrm{P}_{\mathrm{b}}=$ bubble-point pressure (psi).

\section{Almehaideb (1997)}

$\mu_{o}=\mu_{o b}\left(\frac{P}{P_{b}}\right)^{0.134819+1.94345 \cdot 10^{-4} R_{s}-1.93106 \cdot 10^{-9} R_{s}^{2}}$

where $\mu_{\mathrm{ob}}=$ bubble-point oil viscosity (cP), $\mathrm{P}=$ pressure $(p s i), P_{b}=$ bubble-point pressure $(p s i), R_{s}=$ gas-oil ratio (scf/STB).

\section{Elsharkawy and Alikhan (1999)}

$\mu_{o}=\mu_{o b}+\frac{10^{-2.0771}\left(P-P_{b}\right) \mu_{o d}^{1.19279}}{\mu_{o b}^{0.40712} P_{b}^{0.7941}}$

where $\mu_{\mathrm{ob}}=$ bubble-point oil viscosity (cP), $\mu_{\mathrm{od}}=$ dead oil viscosity $(c P), P=$ pressure $(p s i), P_{b}=$ bubble-point pressure (psi).

\section{Dindoruk and Christman (2004)}

$\mu_{o}=\mu_{o b}+0.00006334\left(P-P_{b}\right) \cdot 10^{X}$

$X=C_{1}+C_{2} \log \left(\mu_{o b}\right)-C_{3} \log \left(R_{s}\right)+$

$+C_{4} \mu_{o b} \log \left(R_{s}\right)-C_{5}\left(P-P_{b}\right)$

where $C_{1}=0.776644115, C_{2}=0.987658646, C_{3}=$ $0.190564677, C_{4}=9.147711 \times 10^{-3}, C_{5}=1.9111 \times 10^{-5}$, $\mu_{\mathrm{ob}}=$ bubble-point oil viscosity $(\mathrm{cP}), \mathrm{P}=$ pressure (psi), $P_{b}=$ bubble-point pressure $(p s i), R_{s}=$ gas-oil ratio (scf/STB).

Hossain et al. (2005)

$\mu_{o}=\mu_{o b}+0.004481\left(P-P_{b}\right) \times$

$\times\left(P-P_{b}\right)\left(0.555955 \mu_{o b}^{1.068099}-0.527737 \mu_{o b}^{1.063547}\right)$

where $\mu_{\mathrm{ob}}=$ bubble-point oil viscosity (cP), $\mathrm{P}=$ pressure $(p s i), P_{b}=$ bubble-point pressure (psi).

Bergman and Sutton (2006)

$\mu_{o}=\mu_{o b} \exp \left[\alpha\left(P-P_{b}\right)^{\beta}\right]$

$\beta=2.24623 \cdot 10^{-2} \ln \left(\mu_{o b}\right)+0.873204$

$\alpha=6.5698 \cdot 10^{-7} \ln \left(\mu_{o b}\right)^{2}-1.48211 \cdot 10^{-5} \ln \left(\mu_{o b}\right)+$

$+2.27877 \cdot 10^{-4}$

where $\mu_{\mathrm{ob}}=$ bubble-point oil viscosity (cP), $\mathrm{P}=$ pressure (psi), $\mathrm{P}_{\mathrm{b}}=$ bubble-point pressure (psi).

Isehunwa et al. (2006)

$\mu_{o}=\mu_{o b} \exp \left(1.02 \cdot 10^{-4}\left(P-P_{b}\right)\right)$

where $\mu_{\mathrm{ob}}=$ bubble-point oil viscosity $(\mathrm{cP}), \mathrm{P}=$ pressure (psi), $\mathrm{P}_{\mathrm{b}}=$ bubble-point pressure (psi).

Abedini et al. (2010)

$\mu_{o}=\mu_{o b}+0.001\left(P-P_{b}\right) X$

$X=C_{1} \mu_{o b}^{1.45198}+C_{2} \mu_{o b}^{0.35997}-C_{3} \mu_{o b}^{0.86389}-C_{4} P_{b}^{-0.41866}-($

$-C_{5} P_{b}^{-0.29981}-C_{6} P_{b}^{-0.1946}-C_{7} P_{b}^{-0.31339}$

where $C_{1}=0.05601, C_{2}=0.47557, C_{3}=0.2257, C_{4}=$ $0.29598, C_{5}=0.07734, C_{6}=0.42436, C_{7}=1.64149$, 
$\mu_{\mathrm{ob}}=$ bubble-point oil viscosity $(\mathrm{cP}), \mathrm{P}=$ pressure (psi), $\mathrm{P}_{\mathrm{b}}=$ bubble-point pressure (psi).

\section{Hemmati-Sarapardeh et al. (2013)}

$\mu_{o}=\mu_{o b}+\left(P-P_{b}\right)\left[C_{1}\left(\frac{\mu_{o b}}{P_{b}}\right)^{0.3895556}+\right.$
$\left.+C_{2}\left(\frac{\mu_{o b}}{P_{b}}\right)^{1.226398}+C_{3} \mu_{o b}^{0.001254195 P_{b}+0.3026506}\right]$

where $C_{1}=7.376096 \times 10^{-4}, C_{2}=0.2444663, C_{3}=$ $5.60643 \times 10^{-4}, \mu_{\mathrm{ob}}=$ bubble-point oil viscosity (cP), $\mathrm{P}$ $=\operatorname{pressure}(p s i), P_{b}=$ bubble-point pressure (psi).

\section{Taghizadeh and Eftekhari (2014)}

$\mu_{o}=\mu_{o b} \exp \left[8.85 \cdot 10^{-5}\left(P-P_{b}\right)\right]$

where $\mu_{\mathrm{ob}}=$ bubble-point oil viscosity (cP), $\mathrm{P}=$ pressure (psi), $\mathrm{P}_{\mathrm{b}}=$ bubble-point pressure (psi).

\section{Al-Marhoun (2015)}

$$
\begin{aligned}
& \mu_{o}=\exp \left(\ln \mu_{o b}+0.151292 \cdot 10^{-3} \gamma_{o b}^{2}\left(P-P_{b}\right)\right) \\
& \gamma_{o b}=\left(\gamma_{o}+2.18 \cdot 10^{-4} R_{s} \gamma_{g}\right) / B_{o b}
\end{aligned}
$$

where $\mu_{\mathrm{ob}}=$ bubble-point oil viscosity (cP), $\mathrm{P}=$ pressure $(p s i), P_{b}=$ bubble-point pressure (psi), $B_{o b}$ $=$ bubble-point oil formation-volume-factor (bbl/STB), $\mathrm{R}_{\mathrm{s}}=$ gas-oil ratio (scf/STB).

\section{Alqahtani et al. (2018)}

$$
\begin{aligned}
& \mu_{o}=\mu_{o b}+0.3055\left[0.1323\left(\left[\left(\frac{P}{P_{b}}\right) X\right]-\mu_{o b}\right)-0.0086\right]-0.0099 \\
& X=\left(1.0529\left[0.1317\left(\frac{P}{P_{b}}\right)\left(\mu_{o b}-1.7892\right)\right]\left[\mu_{o b}-3.4466\right]+0.3579+\mu_{o b}\right)
\end{aligned}
$$

where $\mu_{\mathrm{ob}}=$ bubble-point oil viscosity (cP), $\mathrm{P}=$ pressure (psi), $\mathrm{P}_{b}=$ bubble-point pressure (psi). 